NBER WORKING PAPER SERIES

\title{
CEO OVERCONFIDENCE AND INNOVATION
}

\author{
Alberto Galasso \\ Timothy S. Simcoe \\ Working Paper 16041 \\ http://www.nber.org/papers/w16041 \\ NATIONAL BUREAU OF ECONOMIC RESEARCH \\ 1050 Massachusetts Avenue \\ Cambridge, MA 02138
}

May 2010

We thank Ulrike Malmendier for providing the data that made this research possible. We also thank Iain Cockburn, Avi Goldfarb, Teck Ho, Tanjim Hossain, Lisa Kramer, Mark Schankerman, Xianwen Shi, Mo Xiao and seminar participants at the University of Toronto, Ryerson University, the November 2009 NBER Productivity Lunch and the May 2010 Choice Symposium for helpful suggestions. The views expressed herein are those of the authors and do not necessarily reflect the views of the National Bureau of Economic Research.

NBER working papers are circulated for discussion and comment purposes. They have not been peerreviewed or been subject to the review by the NBER Board of Directors that accompanies official NBER publications.

(C) 2010 by Alberto Galasso and Timothy S. Simcoe. All rights reserved. Short sections of text, not to exceed two paragraphs, may be quoted without explicit permission provided that full credit, including (C) notice, is given to the source. 
CEO Overconfidence and Innovation

Alberto Galasso and Timothy S. Simcoe

NBER Working Paper No. 16041

May 2010

JEL No. D80,O31,O32,O33

\begin{abstract}
$\underline{\text { ABSTRACT }}$
Are CEOs' attitudes and beliefs linked to their fims' innovative performance? This paper uses Malmendier and Tate's measure of overconfidence, based on CEO stock-option exercise, to study the relationship between a CEO's "revealed beliefs" about future performance and standard measures of corporate innovation. We begin by developing a career concern model where CEOs innovate to provide evidence of their ability. The model predicts that overconfident CEOs, who underestimate the probability of failure, are more likely to pursue innovation, and that this effect is larger in more competitive industries. We test these predictions on a panel of large publicly traded firms for the years 1980 to 1994 . We nd a robust positive association between overconfidence and citation-weighted patent counts in both cross-sectional and fixed-effect models. This effect is larger in more competitive industries. Our results suggest that overconfident CEOs are more likely to takeltheir firms in a new technological direction.
\end{abstract}

\author{
Alberto Galasso \\ Rotman School of Management \\ University of Toronto \\ 105 St. George Street \\ Toronto, ON \\ CANADA M5S 3E6 \\ Alberto.Galasso@Rotman.Utoronto.Ca \\ Timothy S. Simcoe \\ Boston University \\ School of Management \\ 595 Commonwealth Avenue \\ Boston, MA 02215 \\ and NBER \\ tsimcoe@bu.edu
}




\section{Introduction}

Overconfidence is at odds with standard economic models, which assume that beliefs are correct on average. However, a large body of evidence from applied psychology shows that individuals routinely over-estimate their ability (Svenson, 1981; Cooper et al., 1988). While much of this evidence comes from surveys and lab experiments, there is growing interest in measuring the impact of overconfidence in the field (DellaVigna, 2008). This paper uses a novel measure of CEO overconfidence developed by Malmendier and Tate (2005a, 2005b, 2008, 2010) to study the relationship between managerial overconfidence and corporate innovation.

Prior innovation research has typically invoked overconfidence to explain persistence in the face of long odds, often among entrepreneurs. For instance, Astebro (2003) and Lowe and Ziedonis (2006) ask whether overconfidence is needed to rationalize entrepreneurial behavior, while Arabsheibani et al. (2000) and Simon and Houghton (2003) use survey data to directly assess entrepreneurial confidence levels. Our study departs from this tradition in two important ways. First, we consider the role of overconfidence at the opposite end of the firm-size distribution, among CEOs of large publicly traded companies. And second, instead of asking whether latent overconfidence is required to rationalize observed behavior, we examine the correlation between a novel measure of overconfidence and firm-level innovative performance.

We argue that for large-firm CEOs, the link between overconfidence and innovation does not reflect unreasonable persistence, but rather the propensity to instigate major shifts in strategic direction. And to make this idea precise, we propose a simple career concern model where CEOs decide whether or not to innovate. In this model, successful innovation is rewarded because it reveals new information about managerial ability. However, innovation is also risky: when innovation fails, the market will infer that a CEO lacks talent, and they may be fired. Overconfident CEOs underestimate the likelihood of failure, and are therefore more likely to innovate. This effect is larger in more competitive industries, where success reveals more information about CEO ability, leading to a large payoff that overconfident CEOs are eager to capture.

To test these predictions, we combine standard measures of innovation, based on US patent data, with a measure of CEO overconfidence developed in a series of papers by Malmendier and Tate (2005a, 2005b, 2008, 2010). The measure is constructed by using CEOs' personal investments to capture "revealed beliefs" about their firms' future performance. Specifically, CEOs are classified as overconfident if they hold highly in-the-money stock options after they are fully vested. Our panel data regressions are based on a sample of 290 firms and 627 CEOs during the period 1980 to 1994 . These are large firms, primarily from manufacturing and technology industries, where we observe significant patenting. 
Our main result shows that the arrival of an overconfident CEO is correlated with a 25 to 35 percent increase in citation-weighted patent counts (i.e. citations received by patents filed in a given year). The effect is larger if we assume that a CEO only becomes overconfident after failing to exercise in-the-money option grants, instead of treating overconfidence as a permanent trait. We consider several outcome variables, and find that overconfidence produces similar-sized effects for unweighted patent counts, R\&D expenditure and citations per issued patent. Interacting overconfidence with industry-level measures of competition reveals that this effect is larger when product market competition is more intense.

We extend these main results in several directions. First, we examine the link between overconfidence and two measures of innovative direction, based on the Hall, Jaffe and Trajtenberg (2001) measure of patent originality and a new measure based on self-citation rates. The results suggest that overconfidence leads to a change in direction, and not just an increase in R\&D spending and productivity. Second, we show that the link between overconfidence and innovation is stronger for CEOs who are less constrained. Specifically, the overconfidence effect is larger when a CEO also holds the titles of Chairman and President, or the firm has greater cash flows. These two findings strengthen our preferred interpretation of the main results by showing that overconfidence is more salient when a CEO has greater flexibility to make changes in their firm's strategic direction. Finally, we address the possibility of endogenous matching between firms and CEOs by estimating a model that isolates the impact of within-firm switching from a non-overconfident to an overconfident CEO, and showing that there is no evidence of unusual trends in innovative performance prior to the switch.

Overall, these findings are consistent with theories that predict overconfidence will lead to greater exploration and risk-taking (Bernardo and Welch 2001, Goel and Thakor 2008). This behavior generates positive information externalities, and will benefit shareholders who can bear risk more easily than CEOs. Thus, our findings may help to explain the prevalence of $\mathrm{CEO}$ overconfidence, in spite of the tendency for these executives to destroy value through unprofitable mergers and sub-optimal investment behavior (Malmandier and Tate 2005a, 2005b, $2008,2010)$.

\subsection{Related Literature}

Psychologists have provided a wealth of evidence that individuals over-estimate their own ability. For example, most of us report above the median driving skills (Svenson, 1981), a better than average ability to solve trivia quizzes (Moore and Cain, 2007), and a very good chance of getting the job we desire (Weinstein, 1980). CEOs and other high-ranking executives may be particularly susceptible to this bias, since overconfidence is stronger among highly skilled 
individuals (Camerer and Lovallo, 1999), and when the link between actions and outcomes is complex Moore and Kim (2003).

Given the uncertainty and complexity associated with research and development, we might expect overconfidence to play an important role in the innovation process. In fact, there have been many studies of entrepreneurial overconfidence (see Shane 2003, pg. 12 for a review). But this literature has little to say about psychological biases among large-firm managers, and typically emphasizes the existence of overconfidence rather than its practical effects. We suggest that overconfidence may be important at both large and small firms, and attempt to measure its effect on innovative performance directly. In doing so, we contribute to an emerging literature at the intersection of industrial organization and behavioral economics (see Camerer and Malmendier (2007) for a survey) that has already shown how behavioral biases can influence pricing (DellaVigna and Malmendier, 2006); entry decisions(Goldfarb and Xiao, 2009); labour productivity (Bandiera et al., 2005); bidding in auctions(Brown et al., 2009); and union negotiations (Krueger and Mas, 2004).

Our study builds upon three broad streams of research. First, the data and measure of overconfidence come from Malmendier and Tate (2005a, 2005b, 2008,2010), who use it to study corporate finance. Their key insight is that a CEO's personal financial decisions - specifically, whether they exercise fully vested stock options that are highly in-the-money - can be used to infer beliefs about future performance. As described below, Malmendier and Tate do extensive work to validate this measure, and use it to show that overconfident CEOs are more sensitive to cash flows (Malmendier and Tate, 2005a) and more likely to do mergers and acquisitions (Malmendier and Tate, 2008). Ben David, Harvey and Campbell (2007) use an alternative measure of mis-calibrated expectations and find similar effects on corporate financial decisionmaking. Closer to our work is the study by Hirshleifer et al. (2010), who independently look at the correlation between options- and press-based measures of overconfidence and various measures of risk taking, including patenting and stock-return volatility.

We also build on a long line of research that uses patents to measure corporate innovation. Pakes and Griliches (1980) were the first to estimate a patent production function, and their model was extended by and Hausman, Hall and Griliches (1984), and Blundell, Griffith and Van Reenen (1999). This approach has been used to study the effects of competition (Aghion, Bloom, Blundell, Griffith and Howitt, 1995), R\&D spillovers (Bloom, Schankerman and VanReenen, 2009), and the strengthening of intellectual property protection (Hall and Ziedonis, 2001). Within this literature, our work is closely related to papers that emphasize corporate governance and stock-based compensation, such as Lerner and Wulf (2006), who study the link between innovation and incentive compensation for R\&D managers, or Aghion, Van Reenen and Zingales (2009), who examine the link between institutional shareholding and innovation. 
Finally, our paper adds to a small literature that uses asymmetric beliefs to model the innovation process. In Klepper and Thompson (2007, 2010), asymmetric beliefs about the potential of a new technology lead to spin-outs, whereby entrepreneurs leave incumbent firms to work on a new idea. In our model, an overconfident CEO disagrees with the market's assessment of their ability, and expects to be rewarded if successful innovation persuades the market otherwise. Thus, although we focus on innovation in general, and not the process that gives birth to specific lines of research, both models suggest that innovation can emerge as a response to differences in opinion.

The remainder of the paper is organized as follows. Section 2 presents the model and the empirical predictions. Section 3 describes the data, measures of overconfidence and our econometric framework. Section 4 describes the empirical results. Section 5 concludes.

\section{A Model of Overconfidence and Innovation}

Aghion, Van Reenen and Zingales (2009) extend the Holmstrom (1982) career concern model by allowing the manager to innovate in order to provide evidence of their ability. In this section, we develop a variant of their framework in which we introduce managerial overconfidence.

There are two periods, $t=1,2$. The firm is run by a CEO whose ability $\theta \in\{0, \bar{\theta}\}$ (where $\bar{\theta}>0)$ is unknown to the market, and to the CEO. The market's prior beliefs about CEO ability are:

$$
\operatorname{Pr}_{M}(\theta=\bar{\theta})=\operatorname{Pr}_{M}(\theta=0)=\frac{1}{2} .
$$

The CEO's beliefs about $\theta$ depend on whether they are overconfident. Specifically, we assume:

$$
\begin{aligned}
& \operatorname{Pr}_{C}(\theta=\bar{\theta})=\frac{1}{2}(1+o) \\
& \operatorname{Pr}_{C}(\theta=0)=\frac{1}{2}(1-o)
\end{aligned}
$$

where $0 \leq o \leq 1$ captures CEO overconfidence. When $o=0$ the market and the CEO share prior beliefs, when $o>0$ the CEO thinks that the market underestimates his expected talent. This belief structure is common knowledge. ${ }^{1}$

In period 1, the CEO chooses whether or not to innovate, where the innovation strategy is denoted by $i \in\{0,1\}$. One might think of this as a choice between taking the firm in a

\footnotetext{
${ }^{1}$ See Aumann (1976), Morris (1995) and Yildiz (2004) for a discussion of the role of common priors in economic models. In particular, there is no inconsistency in combining rationality assumptions and heterogenous beliefs because these two assumptions are not related.
} 
new direction, which leads a broad increase in exploration, versus sticking with an established strategy. If the CEO does not innovate $(i=0)$ the revenue realization is equal to zero and no information is revealed about the CEO's ability. If the CEO does innovate $(i=1)$, he incurs an innovation cost, $I$, and the period 1 revenue realization is equal to:

$$
y_{1}=\left\{\begin{array}{c}
1 \text { with probability } p \\
0 \text { with probability } 1-p
\end{array}\right.
$$

if $\theta=\bar{\theta}$ and it is equal to

$$
y_{1}=\left\{\begin{array}{c}
1 \text { with probability } \alpha p \\
0 \text { with probability } 1-\alpha p
\end{array}\right.
$$

if the ability is low.

We define $\alpha \equiv 1-\pi$ where $\pi$ is a measure of product market competition so that the difference in ability is more pronounced when competition is intense. ${ }^{2}$ The term $\alpha$ can be interpreted as a reduced form of an un-modeled race in which a patent is awarded to the best idea in a technology field. The greater the degree of competition, the lower the likelihood that CEOs with low ability will be able to come up with innovations that are superior to those of the competitors. ${ }^{3}$

Following Holmstrom (1982), we assume that the CEO operates in a fully competitive market, and that the second period income of the CEO is equal to the market perception of his expected ability, conditional on the information acquired in period one.

The timing of the game is as follows: (i) the CEO chooses whether to pay $I$ and innovate; (ii) period 1 revenue is realized and observed by the market that updates its assessment of the CEO's talent; (iii) the CEO decides whether to leave the firm based on the comparison between his expected period 2 income and his outside option.

The outside option for a CEO is to reallocate to another sector. As in Aghion, Van Reenen and Zingales (2009), we assume that the ability is sector specific so compensation after relocating is independent of the CEOs current talent and equal to:

\footnotetext{
${ }^{2}$ In the Appendix we show that qualitatively, results would be unchanged if one assumed that competition has an impact on high ability CEOs as long as this impact is not as large as the one on low ability CEOs.

${ }^{3}$ Consider this simple rent seeking game that Baye and Hoppe (2003) show to be strategic equivalent to the classic patent race model of Loury (1979). Two players $H$ (high ability) and $L$ (low ability) exert effort sustaining marginal costs $c_{H}$ and $c_{L}$ with $c_{H}<c_{L}$. The probability that each player obtains the patent is $x_{i} /\left(x_{i}+x_{j}\right)$. If the two players compete, they obtain the patent with probabilities $p_{H}=c_{L} /\left(c_{L}+c_{H}\right)$ and $p_{L}=c_{H} /\left(c_{L}+c_{H}\right)$. Let us now increase competition by introducing a third player with marginal cost $c_{M} \in\left[c_{H}, c_{L}\right]$. The winning probabilities become $p_{H}^{\prime}=\left(c_{L}+c_{M}-c_{H}\right) /\left(c_{L}+c_{M}+c_{H}\right)$ and $p_{L}^{\prime}=\left(c_{H}+c_{M}-c_{L}\right) /\left(c_{L}+c_{M}+c_{H}\right)$. Because $p_{L}-p_{L}^{\prime}>p_{H}-p_{H}^{\prime}$ the increase in competition has a stronger impact on the low ability player than on the high ability player.
} 


$$
\underline{w}=\frac{1}{2} \bar{\theta}-\delta
$$

where $\delta$ is the switching cost.

We solve the model by backward induction. If the CEO decides to innovate, market beliefs follow Bayes' rule. The CEO's income in period 2 if he remains in the firm is equal to:

$$
w_{2}\left(y_{1}\right)=\operatorname{Pr}\left(\theta=\bar{\theta} \mid y_{1}\right) \bar{\theta}
$$

This implies that:

$$
w_{2}\left(y_{1}=1\right)=\frac{p}{p+\alpha p} \bar{\theta}=\frac{\bar{\theta}}{1+\alpha}
$$

and that

$$
w_{2}\left(y_{1}=0\right)=\frac{1-p}{2-p-\alpha p} \bar{\theta} .
$$

We make the following assumption:

$$
\frac{\bar{\theta}}{1+\alpha}>\frac{1}{2} \bar{\theta}-\delta>\frac{1-p}{2-p-\alpha p} \bar{\theta}
$$

which guarantees that the manager will leave the firm if the revenue in period 1 is equal to zero. $^{4}$

In period 1, the CEO will innovate if his expected utility from innovation, $U(i=1)-I$, exceeds the ex-ante utility from not innovating, $U(i=0)$. Because without innovation the market does not update its beliefs we have that:

$$
U(i=0)=\frac{1}{2} \bar{\theta}
$$

If $i=1$, the CEO's expected period 2 compensation is:

$$
\begin{aligned}
U(i & =1)=\left[\frac{1}{2}(1+o) p+\frac{1}{2}(1-o) \alpha p\right] \frac{\bar{\theta}}{1+\alpha} \\
& +\left[\frac{1}{2}(1+o)(1-p)+\frac{1}{2}(1-o)(1-\alpha p)\right] \underline{w}
\end{aligned}
$$

\footnotetext{
${ }^{4}$ Because $\frac{1}{1+\alpha}>\frac{1}{2}>\frac{1-p}{2-p-\alpha p}$ there exists a non empty set of parameters $(\alpha, \bar{\theta}, \delta, p)$ which satisfy A1.
} 
where the first term on the right side of (3) is the ex-ante probability that the CEO assigns to a high revenue realization times $w_{2}\left(y_{1}=1\right)$ and the second term is the ex-ante probability of $y_{1}=0$ times CEO's outside option.

Because the CEO innovates when $U(i=1)-I \geq U(i=0)$ there will be innovation in equilibrium only if innovation costs are not too large, specifically:

$$
I \leq \widehat{I}=\frac{1}{2} p \bar{\theta}+\frac{1}{2}(2-p-\alpha p) \underline{w}-\frac{1}{2} \bar{\theta}+o \frac{p}{2}(1-\alpha)\left(\frac{\bar{\theta}}{1+\alpha}-\underline{w}\right) .
$$

Condition (4) yields two sets of testable implications. The first set of predictions relates to the direct effect of CEO overconfidence. Because

$$
\frac{\partial \widehat{I}}{\partial o}=\frac{p}{2}(1-\alpha)\left(\frac{\bar{\theta}}{1+\alpha}-\underline{w}\right)>0
$$

innovation takes place for a larger range of innovation costs when the CEO is overconfident. We can write this result as:

Implication 1 Overconfident CEOs are more likely to innovate than non-overconfident CEOs.

Second, the model suggests an interplay of product market competition and innovation. The cross-partial derivative

$$
\frac{\partial^{2} \widehat{I}}{\partial o \partial \alpha}=-\frac{p}{2}\left(\frac{\bar{\theta}}{1+\alpha}-\underline{w}\right)-\frac{p}{2} \frac{\bar{\theta}(1-\alpha)}{(1+\alpha)^{2}}<0
$$

and the fact that $\alpha=1-\pi$ imply that overconfidence and competition are complements (i.e. $\left.\partial^{2} \widehat{I} / \partial \circ \partial \pi>0\right)$.

Implication 2 The impact of CEO overconfidence is stronger when product market competition is higher.

\subsection{Discussion}

The model builds on a number of assumptions which are worthy of additional discussion.

First, we assumed that CEO talent is sector specific and that every time a CEO reallocates to another sector he experiences a new draw from the distribution of ability. In the Appendix we show that the model delivers the same set of testable implications if we assume that managerial ability is the same in all sectors. Intuitively, even when poor performance harms both current and future compensation, overconfident CEOs will underestimate the likelihood of doing badly and therefore will be more likely to innovate. We show that the predictions hold even in the 
extreme case in which after a low revenue realization, the CEO leaves the firm and is never hired by other sectors i.e. $\underline{w}=0$.

Second, we assumed that a CEO who reallocates to another sector sustains a switching cost equal to $\delta$. In the Appendix we show that this assumption, despite reducing the likelihood of innovation, has no impact on the effect of overconfidence and on its interaction with product market competition. We also show that the two testable predictions are valid if the innovator does not sustain the private innovation cost $I$. In this case innovation occurs only if $U(i=$ $1) \geq U(i=0)$, which is satisfied as long as the switching cost is below a threshold $\widehat{\delta}$. In the Appendix we show that this threshold increases with $o$, and that $\partial^{2} \widehat{\delta} / \partial o \partial \pi>0$.

Third, our baseline model assumed that there is no impact of competition on non-innovating CEOs. In the Appendix we extend the model assuming that in the absence of innovation the firm may experience a loss and that the likelihood of this loss is greater when competition is intense. In this case competition affects $U(i=0)$ because in the event of a loss the CEO has to reallocate to a different sector. We show that the two testable predictions of our baseline model hold in this alternative environment.

Finally, we assumed that high ability CEOs realize high revenue with probability $p$ whereas low ability CEOs realize it with probability $\alpha p$ with $\alpha$ equal to $1-\pi$. In the Appendix we generalize the framework assuming that the probabilities of high revenue realization are $p(\pi)$ if $\theta=\bar{\theta}$ and $q(\pi)$ if $\theta=0$ with $p(\pi)$ and $q(\pi)$ decreasing functions and $p(\pi)<q(\pi)$. We show that CEO overconfidence has a positive effect on innovation in this generalized setting. We also show that the effect of overconfidence increases with product market competition as long as product market competition has a stronger impact on low talent CEO than on high ability CEOs i.e. $q^{\prime}(\pi)<p^{\prime}(\pi)<0$.

This generalized model highlights a distinction between our setting and the model of Aghion, Van Reenen and Zingales (2009) that assume $p=1-\pi$ (and that $\alpha$ does not depend on $\pi$ ). In their model talent is more valuable when competition is less intense (if $\pi=1$ both types of CEOs realize zero revenue) whereas in our model talent is more valuable when competition is more intense. In the Appendix we show that innovation takes place for a larger range of innovation costs in both models when the CEO is overconfident. Moreover, once we fix the innovation cost $I$, there is a competition-threshold $\pi^{0}$, such that when $\pi \leq \pi^{0}$ both overconfident and non-overconfident CEOs innovate, whereas only overconfident CEOs innovate when $\pi>\pi^{0}$. This implies that in both our baseline model, and the extended version of Aghion, Van Reenen and Zingales (2009), only overconfident CEOs innovate when competition is intense. 


\section{Data and Methods}

\subsection{Data}

We begin with a panel of 450 large publicly traded U.S. firms between 1980 and 1994. These data are described in Hall and Liebman (1998) and Yermack (1995). Each firm in the sample appeared at least four times on a Forbes magazine list of the largest U.S. companies. These data provide a very detailed picture of CEO's stock option holdings, which Malmendier and Tate (2008) use to construct the measure of CEO overconfidence described below.

We use the Compustat firm identifier (GVKEY) to merge this panel of large publicly traded firms to the NBER US patent data file. The NBER patent data are described in Hall et al. (2001), and provide detailed information on all U.S. patents during our sample period, including application and grant years, citations to other patents, and assignee codes that can be used to identify the owner. To match U.S. patent assignee codes with Compustat firms, we started with the name-matching tool of Bessen (2009) and then searched by hand for variations on the names in our panel. After dropping firms in the Finance, Insurance and Real Estate sector (one-digit SIC code 5), which has a very low rate of patenting, we arrive at an estimation sample with 290 firms, 3,648 firm-years and 627 individual CEOs. ${ }^{5}$ Table 1 provides summary statistics for this sample.

Our primary measure of innovation is a citation-weighted count of U.S. patents. This measure builds on a substantial literature that documents the link between patents, citations and firm value (Pakes and Griliches, 1980; Hall et al., 2005; Harhoff et al., 1999; Aghion et al., 2009, inter alia). Patents are assigned to a firm-year observation using their filing date, and we weight each patent by the truncation-adjusted citation count field contained in the NBER data (see Hall et al., 2001, for details).

We also consider several additional innovation metrics. First, we de-compose our primary measure into an unweighted patent count, and the average number of citations per patent (excluding self cites). Second, we use the research and development expenditures (Compustat item 46) as a measure of innovation inputs. Since firms are not required to account for their $\mathrm{R} \& \mathrm{D}$ expenditures, this variable has many missing values, even after we interpolate over any gaps of three years or less. Finally, in a series of extensions, we examine changes in originality and the share of self-citations. Table 1 shows that the distribution of innovative activity in our sample is highly skewed. While the median firm-year observation consists of a single patent that receives 6 citations, the sample mean is much higher, at 28 patents and 489 cites.

To measure competition, we use a Lerner index, as in Aghion et al. (2009). Specifically,

\footnotetext{
${ }^{5}$ Retaining firms from the FIRE sector does not change the main results.
} 
we calculate the median gross margin of all firms in the Compustat database with the same two-digit SIC code as a focal firm. Our baseline model allows this competition measure to vary over time. However, we also consider robustness tests that use a time-invariant Lerner index, or a dummy for firms whose average gross margin over the entire sample period falls above the median of all firms in the estimation sample.

As additional controls, we use on a variety of the accounting data reported by Compustat. Our main Compustat items are sales (item 1); a capital-labor ratio constructed from the book value of total assets (item 6) and the number of employees (item 29); and a deflated R\&D stock. To construct the R\&D stock, we follow the method described in Hall (1990), depreciating all reported $\mathrm{R} \& \mathrm{D}$ activity at a rate of 15 percent over a ten year period. As in Malmedier and Tate (2005a, 2005b, 2008), we construct a measure of cash-flow adding Compustat earnings before extraordinary items (item 18) and depreciation (item 14). We also have several CEO-level control variables used in Malmendier and Tate (2008), including measures of stock and vested option holdings, age, job tenure, and a set of dummies categorizing their educational background as finance or technical. CEOs with a "finance" background received a degree in accounting, finance, business (including MBA) or economics. CEOs with a "technical" background received a degree in engineering, physics, chemistry, mathematics, operations research, biology or applied sciences.

\subsection{Measuring Overconfidence}

Our measures of CEO overconfidence build on a series of papers by Malmendier and Tate. These papers use CEOs' personal investment decisions to construct a proxy for overconfidence, or systematic over-estimation of the returns to holding stock in their own firm. The key idea behind this measurement strategy is to focus on the decision to exercise executive stock options. These options give the holder a right to purchase stock in their own company, usually at the prevailing price on the date of the option grant. They typically have a ten year life, and are

fully exercisable after a four year vesting period. At exercise, the shares are almost always immediately sold (Ofek and Yermack, 2000).

While investors may hold ordinary options because the right to delay a stock purchase has positive value (Merton, 1973), executive stock options have several unique features that create strong incentives for exercise, so long as they are fully vested (and in the money). In particular, executive stock options are non-tradable, and CEOs cannot legally hedge their risk by shortselling shares in their own firm. Moreover, most CEOs are highly exposed to idiosyncratic risk associated with their own firm through equity compensation, stock holdings and firm-specific human capital. Consequently, standard models of decision-making under uncertainty (e.g. Hall 
and Murphy, 2002) indicate that a risk-averse CEO should exercise vested executive options before expiration as long as the stock price is sufficiently high. Nevertheless, many of the CEOs in our sample fail to exercise their executive options, often repeatedly. Malmendier and Tate use this behavior as an indicator of CEO overconfidence, or systematic over-estimation of expected returns from holding the stock.

While there are other potential explanations for a CEO's decision to hold fully vested executive options, Malmendier and Tate (2008) provide strong evidence for the overconfidence interpretation. In particular, their research shows that failure to exercise in-the-money executive options is positively associated with value-destroying merger and acquisition activity, and a relatively high sensitivity of investments to cash flows. These findings are consistent with the idea that overconfident CEOs believe they can make good investments, but perceive the market price of debt financing as too high. Malmendier and Tate also find that CEOs do not earn abnormal returns from holding their executive options, relative to a benchmark case of exercising the options and investing the proceeds in an S\&P 500 stock index. This suggests that "late" exercise does not reflect inside information about the future prospects of the company. After considering a variety of other interpretations (e.g. board pressure, risk-tolerance, taxes and procrastination) Malmendier and Tate (2008) argue that the broad pattern of results is most consistent with the idea that CEOs who fail to exercise their fully vested and in the money executive options are systematically over-estimating the future performance of their own firm, i.e. they are overconfident. We build on the measurement strategy of Malmendier and Tate (2008) to construct two proxies for CEO overconfidence:

Holder67 This indicator variable is identical to the Holder67 variable in Malmendier and Tate (2008). To construct this variable, they examine all CEO option packages five years before expiration (after they are fully vested). The variable Holder 67 equals one for any CEO that fails to exercise an executive option at that time after their stock price has risen by at least 67 percent. This 67 percent exercise threshold is calibrated using the Hall and Murphy (2002) framework, assuming that two-thirds of CEO wealth is tied to company stock. Under this framework, failing to exercise an option that is 67 percent in the money implies a constant relative risk-aversion parameter of three. This measure treats overconfidence as an absorbing state: once a CEO becomes overconfident, they will never change back. While a CEO may switch from "rational" to overconfident within our sample, it is a rare event; most retain their initial classification throughout the sample period.

In our estimation sample, Holder67 classifies roughly half of all CEOs as overconfident. However, a large proportion of all CEOs are not classified, either because they served a short tenure (so there was no opportunity to exercise a fully vested option package), or because their 
stock price did not appreciate by 67 percent. Moreover, Holder67 is only defined for CEOs who have been with a company for at least four years. Thus, our estimation sample contains 1,344 observations where Holder67 is defined. One can think of Holder67 as identifying CEOs who become overconfident following a 67 percent increase in the stock price of their firm. Our second measure is motivated by the idea that overconfidence may be a permanent trait.

Overconfidence This measure is a CEO fixed effect that equals one for all CEOs where Holder67 equals one, and zero for all CEOs where Holder67 equals zero. In practical terms, Overconfidence is simply the maximum value of Holder67 for a given CEO. This is useful for models where we wish to exploit within-firm variation associated with the arrival of an overconfident CEO, as opposed to cross-sectional difference between firms. While Overconfidence is defined for 2,230 observations in our sample, there are still 1,418 observations where it is undefined because of a short tenure or a stock that did not appreciate by at least 67 percent. Our main results are robust re-classifying these missing CEOs as non-onverconfident (though we have no justification for doing so).

Our data have some limitations relative those in Malmendeir and Tate (2008). For example, while they show that the choice of a particular cut-off does not affect the main results, we only observe the Holder67 dummy, and cannot use the detailed option-holdings to construct alternative exercise thresholds. Malmendier and Tate (2008) also use a variable called Longholder, which defines a CEO as overconfident if they hold an executive option until the year of expiration. We do not use this measure because many Longholder CEOs are in non-patenting sectors of the economy, so we are left with only 23 Longholder CEOs in our panel that actually receive a patent.

\subsection{Methods}

Our main econometric models focus on the relationship between count-based measures of innovative activity $Y_{i t}$ at firm $i$ in period $t$, and measures of CEO overconfidence $O_{i t}$. We typically model the conditional expectation of innovative activity as

$$
E\left[Y_{i t}\right]=\exp \left(\alpha O_{i t}+x_{i t-1} \beta+\gamma_{i}+\lambda_{t}\right)
$$

where $x_{i t-1}$ is a vector of control variables (lagged one period to account for obvious forms of simultaneity), $\gamma_{i}$ is a firm-specific idiosyncratic effect, and $\lambda_{t}$ is a vector of time-period effects. Equation (5) uses the log-link formulation because of the non-negative and highly skewed nature of our count-based dependent variables. However, Wooldridge (1999) emphasizes that Poisson quasi maximum-likelihood estimation will yield consistent estimates as long as the conditional 
mean is correctly specified, making it equally appropriate for positive and continuously-valued variables, such as R\&D. We allow for arbitrary heteroskedasticity and autocorrelation (i.e. clustering standard errors). ${ }^{6}$

When $x$ includes measures of the firm's R\&D stock, equation (5) can be interpreted as a "knowledge production function" that translates past research investments into new inventions. In that formulation, $\alpha$ indicates whether firms led by overconfident CEOs receive more citeweighted patents per dollar of R\&D expenditure, so it is a measure of efficiency. We also estimate models that omit the $\mathrm{R} \& \mathrm{D}$ stock from $x$, in which case $\alpha$ measures the combined effect of changes in $R \& D$ stocks and inventive efficiency.

The main method that we use to introduce the firm-specific effects $\gamma_{i}$ in equation (5) is the "mean scaling" estimator of Blundell et al. (1999), that relaxes the strict exogeneity assumption underlying the the fixed-effects Poisson estimator of Hausman et al. (1984). The mean scaling estimator provides consistent estimates under the weaker assumption of predetermined $x_{i t}$ (as long as the first-moments of the data are stable). This method uses pre-sample data on the dependent variable to construct a mean, which then enters the estimation directly (analogously to $x_{i t}$ ) to account for initial conditions. Blundell et al. (1999) show that this approach performs well even with relatively short pre-sample periods. We use ten years of pre-sample data below. In Appendix Table B1 we show that our main results are robust to using the fixed-effects Poisson estimator (Hausman et al., 1984), which is analogous to the familiar within-group OLS estimator.

\section{Results}

\subsection{Overconfidence and Innovation}

Table 2 presents our first set of regression results, which show a robust positive association between CEO overconfidence and innovation. The dependent variable in all models is a citeweighted patent count, or equivalently, a total citation count for the issued patents applied for in year $t$. All models in Table 2 are estimated via Poisson, with robust standard errors to account for over dispersion. Columns (1) through (4) use the Overconfidence measure, while models (5) and (6) consider the alternative Holder67, which leads to a smaller estimation sample.

We begin in column (1) with a pooled cross sectional model that includes only year and twodigit SIC code effects, along with the overconfidence measure. Exponentiating the coefficient of 0.67 suggests that the overconfident CEOs in our sample receive roughly twice as many cite-weighted patents as their non-overconfident counterparts.

\footnotetext{
${ }^{6}$ Our results are robust to clustering standard errors at the level of two digits SIC codes, firms or CEOs.
} 
In column (2) we introduce firm fixed effects using the mean scaling approach of Blundell et al. (1999). While the Overconfidence coefficient falls to 0.39 , or a 48 percent difference in innovative output, the correlation between CEO overconfidence and citation-weighted patents remains quite strong. Column (3) adds controls for sales, the firm's capital to labor ratio, the CEO's age, age squared, the CEO's tenure and tenure squared. This produces almost no change in the Overconfidence coefficient relative to the model containing only the pre-sample means of inventive output.

In columns (1) through (3), the Overconfidence coefficient $\alpha$ measures the joint impact of changes in efficiency (more output per dollar of R\&D) and innovative intensity (greater spending on innovation). In column (4) we add the log of each firm's R\&D stock, so the model becomes a patent production function, where $\alpha$ measures current patenting per dollar of lagged $R \& D$ spending. As expected, we observe a very robust positive correlation between past $R \& D$ and current patenting (see Hall et al., 2005). The coefficient on Overconfidence also declines by about 33 percent, to 0.246 , indicating that Overconfident CEOs obtain 28 percent more citeweighted patents per dollar of lagged $R \& D$ spending than their counterparts. This difference could reflect either a higher patent propensity among overconfident CEOs, or a change in the direction of innovative activity that leads to greater research productivity.

Finally, columns (5) and (6) estimate the same models as columns (3) and (4) using the alternative Holder67 measure of overconfidence. Since Holder67 is only defined starting in the year when a CEO holds a fully vested executive stock option that has appreciated by 67 percent or more, the sample size declines sharply. However, the pattern of results is very similar. While the coefficient on overconfidence is slightly greater, it still falls by about 20 percent when we move to a production function model that includes the R\&D stock. Overall, the results in Table 2 document a strong positive association between overconfidence and innovation that is robust to a variety of measurement and empirical modeling strategies. We take these results as support of the first prediction in the theoretical model.

\subsection{Alternative Innovation Measures}

Table 3 asks whether our baseline results in Table 2 are driven by greater output (more patents), greater input (more R\&D), or greater impact (more cites). We find the answer to be "yes" based on production function estimates with and without firm effects.

The first two columns in Table 3 use unweighted patent counts as the dependent variable. The results in column (1) suggest that overconfident CEOs file for about 20 percent more patents per dollar of lagged R\&D stock than CEOs who are not overconfident. Adding fixed effects in column (2) causes the coefficients on sales and lagged R\&D stock to fall, but has no 
noticeable effect on the Overconfidence coefficient.

The middle two columns examine the link between Overconfidence and R\&D. We drop the lagged R\&D stock in this specification, since we are focused on inputs. In column (3), we find that overconfident CEOs perform about 18 percent more R\&D than a typical CEO. Adding firm effects reduces this effect slightly (to 17 percent).

The last two columns in Table 3 examine the correlation between CEO Overconfidence and citations per patent. The results - both with and without firm effects - show a roughly twenty percent increase in the mean citation rate. Interestingly, there is little correlation between the firm level controls of sales, the capital-labor ratio or the R\&D stock and the average citation rate. We find these last results especially intriguing, as they evoke a change in innovative direction or impact, as opposed to merely an increase in the amount of $R \& D$ or patenting by overconfident CEOs.

\subsection{Overconfidence and Competition}

Table 4 presents several results related to the second prediction of our model. Specifically, the model suggests that the association between overconfidence and innovation will be stronger when firms face more competition. To examine this relationship, we interact the Overconfidence indicator variable with several variations on the Lerner index, or gross margin, which we assume is inversely related to product market competition. All of these regressions use our baseline patent production function specification (see column (4) in Table 2).

Column (1) uses a time-varying Lerner index calculated as the median gross margin of all firms in a particular two-digit SIC code. In this specification, the main effect of Overconfidence is economically large and statistically significant. While the main effect of the Lerner index is negative (less competition yields less innovation), the effect is not statistically significant. To provide a sense of the effect size, we note that a one standard deviation change in the Lerner index (or an additional 5 points of gross margin) is associated with a roughly 3 percent change in cite-weighted patents per dollar of R\&D stock. However, the slope of this relationship between competition and innovation is roughly an order of magnitude larger for overconfident CEOs. In particular, the interaction between Overconfidence and the Lerner index is large and statistically significant, as predicted by our model.

In column (2), we find a qualitatively similar pattern using the Holder67 measure of CEO overconfidence. The main effect of overconfidence is economically large and statistically significant. The main effect of competition is negligible. And the interaction is negative and significant. Once again, the interpretation is that the relationship between Overconfidence and citation-weighted patents is stronger for firms facing more competition. 
Columns (3) and (4) return to our primary Overconfidence measure, but use different measures of competition. In column (3) we restrict the Lerner index to be constant over time, but continue to base the measure on the median gross margin of all Compustat firms in a two-digit SIC code. Note that we cannot estimate a main effect of competition in such a model, since the measure is collinear with industry effects. The results in column (3) are nevertheless very close to those in column (1).

Finally, column (4) measures competition using Lerner50, a dummy for firms in an industry with a time invariant Lerner index that is above the median of all firms in our data set. Thus, we rely on within-sample variation in competition, rather than variation in the entire Compustat dataset. Once again, we find that the relationship between innovation and overconfidence is stronger when competition is more intense.

\subsection{Extensions and Robustness}

\subsubsection{Overconfidence and Innovative Direction}

Next, we use a series of alternative outcome variables to explore the idea that overconfident CEOs do not simply increase the level of innovation, but rather cause a change in the direction pursued by the firms they manage. In columns (1) and (2) of Table 5, the outcome variable is an originality weighted patent count. Originality, as defined in Hall et al. (2001), is essentially one minus a Herfindahl of the concentration of a patent's backwards citations across classes. Thus, more original patents cite a more diverse array of prior art. The results in columns (1) and (2) show that originality weighted patent counts increase with CEO Overconfidence, and more so in industries with lower gross margins.

In columns (3) and (4), we use self-citations to construct a new measure called the Derivative Patent Share. We classify a patent as derivative if more than half of its total citations are to other patents assigned to the same firm, i.e. they are self cites. We then calculate the proportion of all patents that are "derivative" for a given firm-year and use that proportion as our outcome variable. Column (3) shows that there is no meaningful relationship between Overconfidence and the derivative patent share in the pooled panel regressions. However, when Overconfidence is interacted with competition, we find that derivative patenting declines for overconfident CEOs, but increases for overconfident CEOs when there is little competition. This result suggests that overconfident CEOs in profitable industries increase innovation, but focus on familiar problems. Overconfident CEOs in highly competitive fields appear to try for new innovations, perhaps in an effort to escape from the levels of competition at their current product-market location. 


\subsubsection{CEO Autonomy and Cash Flow Sensitivity}

To examine whether the impact of overconfidence is influenced by the degree of autonomy of the CEO, we introduce a dummy for CEOs who also hold the titles of Chairman and President. These titles are used in the corporate governance literature as proxies for centralized executive control over corporate decisions. Thus, we expect the impact of overconfidence to be stronger for CEOs who are also Chairman and President. The coefficients in columns (1) and (2) of Table 6 confirm this prediction and show that the effects of overconfidence and Holder67 are roughly 42 percentage points larger when the CEO has multiple titles.

We also explore the sensitivity of R\&D investments to cash flow. ${ }^{7}$ As stressed in Malmandier and Tate $(2005,2008)$ overconfident CEOs should prefer internal funds to external funds because they perceive their company to be undervalued by the market. Therefore, we should expect $R \& D$ investments of overconfident CEOs to be more sensitive to cash flow. In columns (3) and (4) of Table 6 we control for cash flow and its interaction with the measures of overconfidence. We did not find any significant impact of cash flow on R\&D investment for nonoverconfident CEOs. Conversely, R\&D investments are sensitive to cash flow for overconfident CEOs: the interaction terms are positive and significant. ${ }^{8}$

\subsubsection{Additional Robustness Checks}

Finally, this sub-section describes a variety of additional extensions and robustness checks. Interested readers may refer to Appendix B to find the tables associated with these models.

\section{Endogeneity}

Because overconfident CEOs are not randomly matched to firms, there is a concern that our results may be driven by companies that appoint overconfident CEOs in periods of successful innovation. To take this concern into account, in Appendix Table B2, we use a sub-sample of the larger data set and conduct a within-firm analysis that identifies the Overconfidence effect purely from changes in innovative activity before and after CEO changes that create an increase in overconfidence.

For this analysis, we begin by identifying 28 cases where a CEO who was either notoverconfident or unclassified was replaced by an overconfident CEO (see Table B3 for a list). In each case, we retained data for the four years preceding the switch and all years of data

\footnotetext{
${ }^{7}$ We define cash-flow as Compustat earnings before extraordinary items (item18) plus depreciation (item 14).

${ }^{8}$ We also explored the impact of cash flow on the productivity of R\&D (i.e. citation weighted patent counts). We found that R\&D productivity of overconfident CEOs is sensitive to cash flow only for the most cash constrained firms (those in the bottom quartile of our sample for the Kaplan and Zingales (1996) measure of internal resources).
} 
for the overconfident CEO. To obtain a sample of control switched, we performed a similar exercise to identify cases where a not-overconfident or unclassified CEO was replaced by a notoverconfident CEO. We use this dataset to conduct two types of analysis. First, we compare the change in innovation when the new $\mathrm{CEO}$ is overconfident to the change in innovation when the new CEO is not overconfident, which leads to the familiar difference-differences estimator. Second, we consider the simple before versus after comparison for switches that lead to an overconfident CEO. In the first case, we include a separate time trend for the overconfident and control switches, to test for a difference in the innovation trends across firms prior to the arrival of a new CEO. All of these models are estimated in the fixed-effects Poisson specification to isolate within-firm variation, and we drop the firm-level controls which are unlikely to be strictly exogenous. ${ }^{9}$

The first two columns in Table B2 present the results for citation-weighted patent counts. Column (1) shows the difference in differences results. Following a switch to an overconfident CEO, cite-weighted patents rise by 55 percent more than following a switch to a nonoverconfident CEO. We cannot reject the hypothesis that there is no difference in the pre-switch patenting trends, although the estimated trend during that four year period is roughly twice as high for the firms that received an overconfident CEO. Column (2) focuses on the before versus after comparison within "treated" firms - a regression that would not be identified if all firms switched in the same year. This model shows a large increase in cite-weighted patents following the switch.

Figure 1 provides an alternative look at the impact of a switch to an overconfident CEO on cite-weighted patents. Here, we allow the "treatment effect" to vary for each year, normalizing the coefficient for one year before the switch to zero. The figure shows that there is no discernible trend prior to the switch. In the year of the switch, there is a sharp increase, which doubles over the next two to four years, before levelling off.

Columns (3) and (4) in Table B2 examine un-weighted patent counts. While we find evidence of an increase in patenting, it is less dramatic than the results for citation-weighted patents. The difference in difference estimates show that a 17 percent increase in patenting following a switch to an overconfident CEO. This effect is not statistically different from zero. If we exclude the switches to a non-overconfident CEO the point estimate on patenting increases to 29 percent and is significant at the 10 percent level.

Finally, columns (5) and (6) examine changes in citations per patent. Here we find a large difference in the change between switches to overconfident and non-overconfident CEOs. In

\footnotetext{
${ }^{9}$ We keep CEO controls in the difference in differences analysis but drop them in the before versus after comparison because of the small sample size.
} 
column (5), the coefficient on Overconfidence implies that the patent citation rate increases by 40 percent following the arrival of an overconfident CEO. The effect is small, though still significant at the 10 percent level when we focus on the before-after comparison.

While the analysis of CEO switching helps address concerns about endogenous matching, one might also be concerned about reverse causality. In particular, if an exogenous increase in innovation leads CEOs to become overconfident, and thus hold more options, overconfident CEOs are not affecting innovation; it is innovation that causes overconfidence.

However, we have two pieces of evidence that help distinguish the direction of causality. First, the results in columns (1) and (2) in Table 6 indicate that the correlation between overconfidence and innovation is stronger for CEOs that have greater autonomy. This correlation is difficult to reconcile with reverse causality. In particular, if increased innovation is causing a change in confidence, the results in Table 6 would imply that CEOs with less autonomy become overconfident more easily (i.e. at a lower innovation level) than CEOs with greater control.

Second, to further investigate the direction of causality we split the overconfidence dummy into two separate dummy variables: Pre-Holder67 and Post-Holder67. Post-Holder67 is equal to one only after the CEO reveals his overconfidence for the first time. Including both variables in our baseline regression, we find that only Post-Holder67 is statistically significant, thus suggesting that it is not an increase in patenting activity that induces CEOs to postpone option exercise. ${ }^{10}$

\section{Conditional Fixed Effects}

While the mean scaling estimator allows us to include pre-determined (but not strictly exogenous) firm-level covariates, it does not isolate the within-firm co-variation of overconfidence and innovation (as evidenced by the fact that we can include the SIC effects). To isolate such variation, in Table B1 we rely on the fixed-effects Poisson estimator (Hausman et al., 1984) which is analogous to the familiar within group OLS estimator and assumes that all covariates are strictly exogenous.

In columns (1) and (3) we use the overconfidence dummy and therefore exploit only variation between overconfident and non-overconfident CEOs within firms. In columns (2) and (4) we use the Holder67 dummy and estimate its coefficient using not only within firm variation but also variation between years when a CEOs is classified as overconfident or not. Despite eliminating all cross-sectional variation, we still find support for the two testable implications of our model: overconfidence is positively correlated with innovation and the correlation is stronger when

\footnotetext{
${ }^{10}$ We also examined whether the increase in patenting was concentrated in the first two years after the overconfidence is revealed. We find that there is no statistical difference between innovation in the first 2 years after overconfidence is revealed and innovation in the subsequent years.
} 
product market competition is intense. While many of our other results are robust to this alternative estimator, some lose statistical significance. This is not surprising given the limited CEO turnover within firms: Table 2 shows that we observe only 1.3 CEOs per firm in our main regressions.

\section{Alternative Controls and Specifications}

In Table B4 we present a series of extensions that demonstrate the robustness of our main results to including extra covariates and changing the model specification. In column (1) we show that our estimates are not affected when we control for vested option holdings (options that are exercisable within six months as a fraction of common shares outstanding) and stock ownership (fraction of stock owned by the CEO and his immediate family). In column (2) we control for $\mathrm{CEO}$ educational background. Although we lose roughly 32 percent of the observations because of missing data on educational background, there is essentially no change in the overconfidence coefficient. In column (3) we allow for dynamics using a multiplicative feedback model that controls for the logarithm of lagged cite-weighted patent counts. Not surprisingly we found strong persistence in patenting; the coefficient on lagged patents is highly significant. The coefficient on overconfidence is positive and significant at the 0.1 level. Finally, in column (4) we show that results are similar when using a negative binomial regression model.

\section{Execucomp Data}

Our main analysis uses a dataset originally constructed by Yermack (1995), Hall and Liebman (1998) and Malmandier and Tate (2005a; 2005b; 2008). The main virtue of these data is the presence of Holder67, the measure of overconfidence developed by Malmendier and Tate (2008). Their primary limitation is the small sample, which contains only 290 innovating firms. In this final sub-section, we explore the relation between overconfidence and innovation using the larger S\&P ExecuComp Compustat database, which reports information on executive compensation for S\&P 1,500 companies from 1992 to 2009. To avoid truncation problems with the patent data, we focus on the period 1992-2001.

The ExecuComp dataset provides information both on the salary and on the aggregate value of the stock options awarded to the CEOs. Because grant and expiration date of the individual option packages are not reported, we cannot construct the Holder 67 measure. Nevertheless, we constructed an alternative measure, Holder67-EC, based on aggregate stock option holdings but similar in spirit to Holder67. ${ }^{11}$ Intuitively, we identified the CEOs that did not exercise

\footnotetext{
${ }^{11}$ Dezso and Ross (2010) use a similar measure to examine the correlation between CEO options-holding and the cost of borrowing.
} 
a substantial amount of their stock options despite a considerable increase in the underlying stock value.

Specifically, we focus on CEOs that during their tenure experienced an increase of at least 67 percent in the stock price over a 5 year period. For all these CEOs, we constructed the ratio between the value of unexercised exercisable options and the CEOs salary and bonus. Finally, we classified a CEO as a Holder67-EC if after a 67 percent stock price increase, the ration of vested option to income was above the 95th percentile of the entire options-income distribution. ${ }^{12}$ As for the Holder67 measure, once a CEO is classified as Holder67-EC he keeps that label for the remaining sample years. We also created a variable Overconfidence-EC equal to the maximum of Holder67-EC.

In the new sample, there are 1899 CEOs for which Overconfidence-EC is defined. About ten percent of these CEOs are classified as overconfident. The final sample contains 1491 innovating firms and 7123 observations. The mean firm-year observation consists of 20 patents that receive 344 citations. The average firm in the new sample has 5,365 employees whereas the average firm in the dataset described in Section 3 has 14,565 employees.

Appendix Table B5 investigates the relation between overconfidence and innovation in this alternative sample. The coefficients on Overconfidence-EC and Holder67-EC are positive and significant thus supporting the first testable implication of our theoretical model. We also find support for the second prediction, the coefficient on the interaction between the Lerner index and overconfidence is negative and significant.

\section{Conclusions}

In this paper we study the relationship between CEO overconfidence and innovation. We use a simple career concern model to show that CEO overconfidence can increase innovation. The model also predicts that the impact of overconfidence will be stronger when product market competition is more intense. We find strong empirical support for these predictions. In particular, overconfident CEOs obtain more cite-weighted patents, and this effect increases with product market competition.

These findings suggest that overconfident CEOs are more likely to initiate a significant change in their firm's innovation strategy. They also suggest that applying tools from behavioral economics to questions in the field of innovation may yield novel insights into the determinants

\footnotetext{
${ }^{12}$ We experimented with alternative cutoff rules $(75 \mathrm{th}, 85 \mathrm{th}$ and 90 th percentiles of the option-income ratio distribution) and found that the correlation between innovation and overconfidence is robust to variation in the value of the threshold. The interaction effect with product market competition is more sensitive to the cutoff rule, and results are consistent with Implication 2 only for cutoff rules above the 90th percentile.
} 
of R\&D investments and patenting. Our findings are complementary to those in Aghion, Van Reenen and Zingales (2009). While they show that institutional ownership encourages innovation by reducing the likelihood that a CEO is dismissed after a decline in profits, our results show that overconfidence encourage innovation by reducing the CEOs internal beliefs about the likelihood of failure. 


\section{References}

Aghion, P., N. Bloom, R. Blundell, R. Griffith, and P. Howitt (2005). Competition and Innovation: An Inverted-U Relationship? The Quarterly Journal of Economics 120(2), 701-728.

Aghion, P., J. Van Reenen, and L. Zingales (2009). Innovation and Institutional Ownership. NBER Working Paper 14769.

Arabsheibani, G., D. de Meza, J. Maloney, and B. Pearson (2000). And a vision appeared unto them of a great profit: Evidence of self-deception among the self-employed. Economics Letters 67, 35-41.

Astebro, T. (2003). The Return to Independent Invention: Evidence of Risk Seeking, Extreme Optimism or Skewness-Loving. The Economic Journal 113, 226-239.

Bandiera, O., I. Barankay, and I. Rasul (2005). Social Preferences and the Response to Incentives: Evidence from Personnel Data. The Quarterly Journal of Economics 120(3), 917-962.

Baye, M. R. and H. C. Hoppe (2003). The strategic equivalence of rent-seeking, innovation, and patentrace games. Games and Economic Behavior 44 (2), 217-226.

Ben-David, I., J. R. Graham, and C. R. Harvey (2008). Managerial Overconfidence and Corporate Policies. Working paper.

Bernardo, A. E. and I. Welch (2001). On the Evolution of Overconfidence and Entrepreneurs. Journal of Economics 83 Management Strategy 10(3), 301-330.

Bessen, J. (2009). Tool for Matching Assignee Names. Technical report, NBER Patent Data Project.

Bloom, N., M. Schankerman, and J. Van Reenen (2005). Identifying Technology Spillovers and Product Market Rivalry. CEPR Discussion Papers 4912, C.E.P.R. Discussion Papers.

Blundell, R., R. Griffith, and J. van Reenen (1999). Market Share, Market Value and Innovation in a Panel of British Manufacturing Firms. Review of Economic Studies 66(3), 529-54.

Brown, J., T. Hossain, and J. Morgan (2009). Shrouded Attributes and Information Suppression: Evidence from the Field. The Quarterly Journal of Economics forthcoming.

Camerer, C. and D. Lovallo (1999). Overconfidence and Excess Entry: An Experimental Approach. American Economic Review 89(1), 306-318.

Camerer, C. and U. Malmendier (2007). Behavioral Economics and its Applications, Chapter Behavioral Economics of Organizations. Princeton University Press.

Cooper, A. C., C. Y. Woo, and W. C. Dunkelberg (1988). Entrepreneurs' perceived chances for success. Journal of Business Venturing 3, 97-108.

De Meza, D. and C. Southey (1996). The borrowers curse: Optimism finance and entrepreneurship. the Economic Journal 106, 375-386. 
DellaVigna, S. (2008). Psychology and Economics: Evidence from The Field. Journal of Economic Literature 47(2), 315-372.

DellaVigna, S. and U. Malmendier (2006). Paying Not to Go to the Gym. American Economic Review $96(3), 694-719$.

Dezso, C. and D. G. Ross (2010). Are Banks Happy when Managers Go Long? Vested Options and the Cost of Private Debt. SSRN Working Paper.

Goel, A. M. and A. V. Thakor (2008). Overconfidence, CEO Selection, and Corporate Governance. Journal of Finance 63(6), 2737-2784.

Goldfarb, A. and M. Xiao (2009). Who Thinks About the Competition? Managerial Ability and Strategic Entry in Local Telephone Markets. University of Toronto Working Paper.

Hall, B. H. (1990). The Manufacturing Sector Master File: 1959-1987. NBER Working Paper No. 3366.

Hall, B. H., A. B. Jaffe, and M. Trajtenberg (2001). The NBER Patent Citation Data File: Lessons, Insights and Methodological Tools. Working Paper 8498, National Bureau of Economic Research.

Hall, B. H., A. B. Jaffe, and M. Trajtenberg (2005). Market Value and Patent Citations. RAND Journal of Economics 36, 16-38.

Hall, B. H. and R. H. Ziedonis (2001). The Patent Paradox Revisited: An Empirical Study of Patenting in the U.S. Semiconductor Industry, 1979-1995. RAND Journal of Economics 32(1), 101-128.

Hall, B. J. and J. B. Liebman (1998). Are CEOs Really Paid Like Bureaucrats? The Quarterly Journal of Economics 113(3), 653-691.

Hall, B. J. and K. J. Murphy (2002). Stock options for undiversified executives. Journal of Accounting and Economics 33(1), 3-42.

Harhoff, D., F. Narin, F. M. Scherer, and K. Vopel (1999). Citation frequency and the value of patented inventions. Review of Economics and Statistics 81(3), 511-515.

Hausman, J., B. Hall, and Z. Griliches (1984). Econometric Models for Count Data with an Application to the Patents-R\&D Relationship. Econometrica 52(4), 909-938.

Hirshleifer, D. A., S. H. Teoh, and A. Low (2010). Are Overconfident CEOs Better Innovators? SSRN Working Paper.

Holmstrom, B. (1999). Managerial Incentive Problems: A Dynamic Perspective. Review of Economic Studies 66(1), 169-82.

Kaplan, S. and L. Zingales (1997). Do investment-cash flow sensitivities provide useful measures of financing constraints? Quarterly Journal of Economics 112, 169-215. 
Klepper, S. and P. Thompson (2007). Perspectives on Innovation, Chapter Spinoff Entry in High-Tech Industries: Motives and Consequences (chapter6), pp. 187-218. Cambridge University Press.

Klepper, S. and P. Thompson (2010). Disagreement and Intra-industry spinoffs. International Journal of Industrial Organization forthcoming.

Krueger, A. B. and A. Mas (2004). Strikes, Scabs, and Tread Separations: Labor Strife and the Production of Defective Bridgestone/Firestone Tires. Journal of Political Economy 112(2), 253-289.

Loury, G. C. (1979). Market Structure and Innovation. The Quarterly Journal of Economics 93(3), 395-410.

Lowe, R. A. and A. A. Ziedonis (2006). Overoptimism and the Performance of Entrepreneurial Firms. Management Science 52, 173-186.

Malmendier, U. and G. Tate (2005a). CEO Overconfidence and Corporate Investment. Journal of Finance 60(6), 2661-2700.

Malmendier, U. and G. Tate (2005b). Does Overconfidence Affect Corporate Investment? CEO Overconfidence Measures Revisited. European Financial Management 11(5), 649-659.

Malmendier, U. and G. Tate (2008). Who makes acquisitions? CEO overconfidence and the market's reaction. Journal of Financial Economics 89(1), 20-43.

Malmendier, U., G. Tate, and J. Yan (2010). Managerial Beliefs and Corporate Financial Policies. working paper.

Merton, R. C. (1973). Theory of Rational Option Pricing. Bell Journal of Economics 4(1), 141-183.

Moore, D. and T.-G. Kim (2003). Myopic Social Prediction and the Solo Comparison Paradox. Journal of Personality and Social Psychology 85, 1121-1135.

Moore, D. A. and D. M. Cain (2007). Overconfidence and underconfidence: When and why people underestimate (and overestimate) the competition. Organizational Behavior and Human Decision Processes 103(2), 197-213.

Morris, S. (1995). The Common Prior Assumption in Economic Theory. Economics and Philosophy 11, $227-253$.

Ofek, E. and D. Yermack (2000). Taking Stock: Equity-Based Compensation and the Evolution of Managerial Ownership. Journal of Finance 55(3), 1367-1384.

Pakes, A. and Z. Griliches (1980). Patents and R\&D at the firm level: A first report. Economics Letters 5(4), 377-381.

Rabin, M. (1998). Psychology and Economics. Journal of Economic Literature 36(1), 11-46.

Shane, S. (2003). A general theory of entrepreneurship: the individual-opportunity nexus. Edward Elgar. 
Simon, M. and S. M. Houghton (2003). The relationship between overconfidence and the introduction of risky products: Evidence from a field study. The Academy of Management Journal 46, 139-149.

Svenson, O. (1981). Are we all less risky and more skillful than our fellow drivers? Acta Psychologica $47(2), 143-148$.

Weinstein, N. (1980). Unrealistic Optimism about Future Life Events. Journal of Personality and Social Psychology 39, 806-820.

Wooldridge, J. M. (1999). Distribution-free estimation of some nonlinear panel data models. Journal of Econometrics 90(1), 77-97.

Yermack, D. (1995). Do corporations award CEO stock options effectively? Journal of Financial Economics 39(2-3), 237-269.

Yildiz, M. (2004). Waiting to Persuade? Quarterly Journal of Economics 119, 223-249. 


\section{Tables and Figures}

Table 1: Summary Statistics

\begin{tabular}{|c|c|c|c|c|c|c|}
\hline & Mean & Median & Min & Max & S.D. & Obs. \\
\hline Total Cites & 489.01 & 6.00 & 0.00 & 32,509 & 1,747 & 3648 \\
\hline Total Patents & 27.79 & 1.00 & 0.00 & 1,221 & 81.29 & 3648 \\
\hline Cites per Patent & 8.62 & 4.00 & 0.00 & 240 & 13.32 & 3648 \\
\hline $\log (\mathrm{R} \& \mathrm{D}$ Expense $)$ & 3.80 & 3.92 & 0.00 & 8.73 & 1.94 & 1864 \\
\hline Overconfidence & 0.58 & 1.00 & 0.00 & 1.00 & 0.49 & 2441 \\
\hline Holder67 & 0.49 & 0.00 & 0.00 & 1.00 & 0.50 & 1533 \\
\hline Lerner Index & 0.11 & 0.09 & 0.03 & 0.22 & 0.05 & 3648 \\
\hline CEO Chairman & 0.38 & 0.00 & 0.00 & 1.00 & 0.49 & 3640 \\
\hline $\log$ (Cash Flow) & 5.31 & 5.33 & -5.45 & 13.92 & 1.51 & 3624 \\
\hline $\log ($ Sales $)$ & 7.85 & 7.75 & 2.95 & 11.81 & 1.12 & 3641 \\
\hline $\log ($ Employees $)$ & 2.68 & 2.72 & -2.23 & 6.78 & 1.29 & 3627 \\
\hline $\log ($ Capital/Labor $)$ & 4.29 & 4.01 & 0.09 & 7.47 & 1.35 & 3637 \\
\hline Total Firms & \multicolumn{6}{|c|}{290} \\
\hline Total CEOs & \multicolumn{6}{|c|}{627} \\
\hline Overconfident & \multicolumn{6}{|c|}{168} \\
\hline Not-overconfident & \multicolumn{6}{|c|}{136} \\
\hline Unclassified & \multicolumn{6}{|c|}{323} \\
\hline
\end{tabular}

Holder67 is a dummy equal to 1 for all CEO years after the CEO fails to exercise an option $67 \%$ in the money with 5 years remaining duration. Overconfidence is the maximum value for Holder67 for a given CEO. Lerner Index is the median gross profit margin of all Compustat firms in a 2-digit SIC code. Cash Flow equals Compustat earnings before extraordinary items (item 18) plus depreciation (item 14). CEO Chairman is a dummy equal to one if a CEO also holds the titles of Chairman and President. 
Table 2: Overconfidence and Innovation

\begin{tabular}{|c|c|c|c|c|c|c|}
\hline \multicolumn{7}{|c|}{$\begin{array}{c}\text { Poisson Panel Regressions } \\
\text { Unit of Observation = Firm-Year } \\
\text { Dependent Variable = Total Cites }\end{array}$} \\
\hline & $(1)$ & $(2)$ & $(3)$ & $(4)$ & $(5)$ & (6) \\
\hline Overconfidence & $\begin{array}{c}0.674^{* * *} \\
(0.22)\end{array}$ & $\begin{array}{c}0.389^{* *} \\
(0.16)\end{array}$ & $\begin{array}{c}0.360^{* * *} \\
(0.13)\end{array}$ & $\begin{array}{c}0.246^{* *} \\
(0.11)\end{array}$ & & \\
\hline Holder67 & & & & & $\begin{array}{c}0.548^{* * *} \\
(0.13)\end{array}$ & $\begin{array}{c}0.411^{* * *} \\
(0.12)\end{array}$ \\
\hline $\ln$ (Sales) & & & $\begin{array}{c}0.414^{* * *} \\
\quad(0.11)\end{array}$ & $\begin{array}{c}0.202^{*} \\
(0.12)\end{array}$ & $\begin{array}{c}0.415^{* * *} \\
(0.11)\end{array}$ & $\begin{array}{c}0.056 \\
(0.12)\end{array}$ \\
\hline ln(Capital/Labor) & & & $\begin{array}{r}-0.062 \\
(0.13)\end{array}$ & $\begin{array}{c}0.088 \\
(0.10)\end{array}$ & $\begin{array}{c}0.116 \\
(0.17)\end{array}$ & $\begin{array}{c}0.298^{* *} \\
(0.12)\end{array}$ \\
\hline $\ln (\mathrm{R} \& \mathrm{D}$ Stock $)$ & & & & $\begin{array}{c}0.324^{* * *} \\
(0.08)\end{array}$ & & $\begin{array}{c}0.497^{* * *} \\
(0.09)\end{array}$ \\
\hline Year Effects & Yes & Yes & Yes & Yes & Yes & Yes \\
\hline SIC 2-digit Effects & Yes & Yes & Yes & Yes & Yes & Yes \\
\hline CEO Controls & No & No & Yes & Yes & Yes & Yes \\
\hline BGV Firm Effects & No & Yes & Yes & Yes & Yes & Yes \\
\hline Observations & 2441 & 2441 & 2441 & 2441 & 1512 & 1512 \\
\hline Firms & 229 & 229 & 227 & 227 & 226 & 226 \\
\hline $\mathrm{CEOs}$ & 303 & 303 & 301 & 301 & 301 & 301 \\
\hline
\end{tabular}


Table 3: Overconfidence and Alternative Innovation Measures

\section{Poisson Panel Regressions}

Unit of Observation $=$ Firm-Year

\begin{tabular}{|c|c|c|c|c|c|c|}
\hline \multirow[t]{2}{*}{ Outcome Variable } & \multicolumn{2}{|c|}{$\begin{array}{c}\text { Unweighted } \\
\text { Patents }\end{array}$} & \multicolumn{2}{|c|}{$\begin{array}{c}\text { R\&D } \\
\text { Expense }\end{array}$} & \multicolumn{2}{|c|}{$\begin{array}{c}\text { Citations } \\
\text { per Patent }\end{array}$} \\
\hline & $(1)$ & $(2)$ & $(3)$ & $(4)$ & $(5)$ & (6) \\
\hline Overconfidence & $\begin{array}{c}0.199^{* *} \\
(0.10)\end{array}$ & $\begin{array}{c}0.183^{* * *} \\
(0.06)\end{array}$ & $\begin{array}{c}0.164^{*} \\
(0.08)\end{array}$ & $\begin{array}{c}0.155^{* *} \\
(0.06)\end{array}$ & $\begin{array}{c}0.198^{* * *} \\
(0.07)\end{array}$ & $\begin{array}{c}0.202^{* * *} \\
(0.07)\end{array}$ \\
\hline $\ln (\mathrm{R} \& \mathrm{D}$ Stock $)$ & $\begin{array}{c}0.428^{* * *} \\
(0.05)\end{array}$ & $\begin{array}{c}0.229^{* * *} \\
(0.07)\end{array}$ & & & $\begin{array}{c}0.018 \\
(0.10)\end{array}$ & $\begin{array}{c}-0.004 \\
(0.10)\end{array}$ \\
\hline $\ln$ (Sales) & $\begin{array}{c}0.400^{* * *} \\
(0.08)\end{array}$ & $\begin{array}{c}0.190^{* * *} \\
(0.06)\end{array}$ & $\begin{array}{c}1.057^{* * *} * \\
(0.10)\end{array}$ & $\begin{array}{c}0.767^{* * *} * \\
(0.06)\end{array}$ & $\begin{array}{l}0.047 \\
(0.14)\end{array}$ & $\begin{array}{l}0.043 \\
(0.13)\end{array}$ \\
\hline $\ln$ (Capital/Labor) & 0.039 & 0.041 & $-0.339 *$ & $-0.276^{* * *}$ & 0.023 & 0.038 \\
\hline Year Effects & Yes & Yes & Yes & Yes & Yes & Yes \\
\hline SIC 2-digit Effects & Yes & Yes & Yes & $\mathrm{n} / \mathrm{a}$ & Yes & Yes \\
\hline CEO Controls & Yes & Yes & Yes & Yes & Yes & Yes \\
\hline Firm Effects & No & $\mathrm{BGV}$ & No & Yes & No & BGV \\
\hline Observations & 2229 & 2229 & 1216 & 1199 & 2229 & 2229 \\
\hline Firms & 209 & 209 & 123 & 119 & 209 & 209 \\
\hline CEOs & 279 & 279 & 167 & 163 & 279 & 279 \\
\hline
\end{tabular}

Cluster robust standard errors in parentheses: $* 10 \%$ significance; $* * 5 \%$ significance; $* * * 1 \%$ significance. Overconfidence is the maximum value for Holder67 for a given CEO where Holder67 is a dummy equal to 1 for all CEO years after the CEO fails to exercise an option $67 \%$ in the money with 5 years remaining duration. BGV fixed effects are based on including pre-sample means of the dependent variable. CEO controls are Age, $\mathrm{Age}^{2}$, Tenure and Tenure ${ }^{2}$. 
Table 4: Competition Interactions

\section{Poisson Panel Regressions}

Unit of Observation $=$ Firm-Year

Dependent Variable $=$ Total Cites

\begin{tabular}{|c|c|c|c|c|}
\hline & (1) & $(2)$ & $(3)$ & $(4)$ \\
\hline Overconfidence & $\begin{array}{c}0.744^{* * *} \\
(0.18)\end{array}$ & & $\begin{array}{c}0.643^{* * *} \\
(0.23)\end{array}$ & $\begin{array}{c}0.330^{* * *} \\
(0.12)\end{array}$ \\
\hline Lerner Index & $\begin{array}{l}-0.487 \\
(4.12)\end{array}$ & $\begin{array}{l}-0.947 \\
(4.07)\end{array}$ & & \\
\hline Lerner x Overconf & $\begin{array}{c}-4.630^{* * *} \\
(1.07)\end{array}$ & & & \\
\hline Holder67 & & $\begin{array}{c}0.690^{* * *} \\
(0.19)\end{array}$ & & \\
\hline Lerner x Holder67 & & $\begin{array}{c}-2.830^{* *} \\
(1.35)\end{array}$ & & \\
\hline LernerSIC x Overconf & & & $\begin{array}{c}-3.598^{* *} \\
(1.49)\end{array}$ & \\
\hline Lerner50 x Overconf & & & & $\begin{array}{c}-0.505^{* *} \\
(0.24)\end{array}$ \\
\hline Year Effects & Yes & Yes & Yes & Yes \\
\hline SIC 2-digit Effects & Yes & Yes & Yes & Yes \\
\hline Firm Effects & BGV & BGV & BGV & BGV \\
\hline Observations & 2200 & 1344 & 2200 & 2200 \\
\hline Firms & 207 & 200 & 207 & 207 \\
\hline CEOs & 277 & 270 & 277 & 277 \\
\hline
\end{tabular}

Cluster robust standard errors in parentheses: $* 10 \%$ significance; $* * 5 \%$ significance; *** $1 \%$ significance. Holder 67 is a dummy equal to 1 for all CEO years after the CEO fails to exercise an option $67 \%$ in the money with 5 years remaining duration. Overconfidence is the maximum value for Holder67 for a given CEO. Lerner Index is the median gross profit margin of all Compustat firms in a 2-digit SIC code (see text). BGV fixed effects are based on including presample means of the dependent variable. All models control for $\ln (\mathrm{R} \& \mathrm{D}$ Stock), $\ln$ (Sales), $\ln$ (Capital/Labor) and CEO Age, Age $^{2}$, Tenure and Tenure ${ }^{2}$. 
Table 5: Overconfidence and Innovative Direction

\begin{tabular}{|c|c|c|c|c|}
\hline \multicolumn{5}{|c|}{$\begin{array}{l}\text { Panel Regressions } \\
\text { Unit of Observation = Firm-Year }\end{array}$} \\
\hline \multirow[t]{2}{*}{ Outcome Variable } & \multicolumn{2}{|c|}{$\begin{array}{c}\text { Originality } \\
\text { Weighted Patents }\end{array}$} & \multicolumn{2}{|c|}{$\begin{array}{c}\text { Derivative } \\
\text { Patent Share }\end{array}$} \\
\hline & $\begin{array}{l}\text { Poisson } \\
\quad(1)\end{array}$ & $\begin{array}{l}\text { Poisson } \\
\quad(2)\end{array}$ & $\begin{array}{l}\text { OLS } \\
(3)\end{array}$ & $\begin{array}{l}\text { OLS } \\
(4)\end{array}$ \\
\hline Overconfidence & $\begin{array}{c}0.188^{* *} \\
(0.08)\end{array}$ & $\begin{array}{l}0.406^{* * *} \\
\quad(0.13)\end{array}$ & $\begin{array}{r}-0.006 \\
(0.01)\end{array}$ & $\begin{array}{c}-0.031^{* *} \\
(0.01)\end{array}$ \\
\hline Lerner SIC x Overconf & & $\begin{array}{c}-2.055^{*} \\
(1.24)\end{array}$ & & $\begin{array}{c}0.275^{* *} \\
(0.11)\end{array}$ \\
\hline Year Effects & Yes & Yes & Yes & Yes \\
\hline SIC 2-digit Effects & Yes & Yes & $\mathrm{n} / \mathrm{a}$ & $\mathrm{n} / \mathrm{a}$ \\
\hline Firm Effects & $\mathrm{BGV}$ & BGV & Yes & Yes \\
\hline Observations & 2124 & 2124 & 1343 & 1343 \\
\hline Firms & 199 & 199 & 155 & 155 \\
\hline CEOs & 268 & 268 & 206 & 206 \\
\hline
\end{tabular}

Cluster robust standard errors in parentheses: $* 10 \%$ significance; $* * 5 \%$ significance; $* * * 1 \%$ significance. See Hall et al. (2001) for a definition of originality. Derivative patents have more than 50 percent of self-citations. Overconfidence is the maximum value for Holder67 for a given CEO where Holder67 is a dummy equal to 1 for all CEO years after the CEO fails to exercise an option $67 \%$ in the money with 5 years remaining duration. Lerner Index is the median gross profit margin of all Compustat firms in a 2-digit SIC code (see text). LernerSIC and Lerner50 are alternative measures of industry grossprofitability that exclude longitudinal variation (see text). BGV fixed effects are based on including pre-sample means of the dependent variable. All models control for $\ln (\mathrm{R} \& \mathrm{D}$ Stock), $\ln$ (Sales), $\ln$ (Capital/Labor) and CEO Age, Age $^{2}$, Tenure and Tenure ${ }^{2}$. 
Table 6: CEO Independence and Cash Flow Interactions

\begin{tabular}{|c|c|c|c|c|}
\hline \multicolumn{5}{|c|}{$\begin{array}{c}\text { Poisson Panel Regressions } \\
\text { Unit of Observation = Firm-Year }\end{array}$} \\
\hline \multirow[t]{2}{*}{ Outcome Variable } & \multicolumn{2}{|c|}{ Total Cites } & \multicolumn{2}{|c|}{ R\&D Expense } \\
\hline & (1) & $(2)$ & $(3)$ & $(4)$ \\
\hline Overconfidence & $\begin{array}{l}0.135 \\
(0.12)\end{array}$ & & $\begin{array}{c}-0.297^{*} \\
(0.16)\end{array}$ & \\
\hline CEO-Chairman & $\begin{array}{c}-0.184^{*} \\
(0.11)\end{array}$ & $\begin{array}{c}-0.132 \\
(0.09)\end{array}$ & & \\
\hline Overconf x CEO-Chair & $\begin{array}{c}0.352^{* *} \\
(0.15)\end{array}$ & & & \\
\hline Holder67 & & $\begin{array}{l}0.316^{* * *} \\
\quad(0.10)\end{array}$ & & $\begin{array}{c}-0.327^{*} \\
(0.19)\end{array}$ \\
\hline Holder67 x CEO-Chair & & $\begin{array}{l}0.387^{* * *} \\
(0.12)\end{array}$ & & \\
\hline $\ln ($ CashFlow $)$ & & & $\begin{array}{r}-0.033 \\
(0.02)\end{array}$ & $\begin{array}{r}-0.011 \\
(0.03)\end{array}$ \\
\hline Overconf $\mathrm{x} \ln$ (CashFlow) & & & $\begin{array}{l}0.063^{* * *} \\
(0.02)\end{array}$ & \\
\hline Holder67 x $\ln$ (CashFlow $)$ & & & & $\begin{array}{r}0.050^{*} \\
(0.03)\end{array}$ \\
\hline Year Effects & Yes & Yes & Yes & Yes \\
\hline SIC 2-digit Effects & Yes & Yes & $\mathrm{N} / \mathrm{A}$ & $\mathrm{N} / \mathrm{A}$ \\
\hline CEO Controls & Yes & Yes & No & No \\
\hline Firm Effects & $\mathrm{BGV}$ & $\mathrm{BGV}$ & Yes & Yes \\
\hline Observations & 2195 & 1344 & 1199 & 747 \\
\hline Firms & 207 & 200 & 119 & 113 \\
\hline CEOs & 277 & 270 & 163 & 155 \\
\hline
\end{tabular}

Cluster robust standard errors in parentheses: $* 10 \%$ significance; $* * 5 \%$ significance; $* * * 1 \%$ significance. CEO Chairman is a dummy equal to one if a CEO also holds the titles of Chairman and President. Cash Flow equals Compustat earnings before extraordinary items (item 18) plus depreciation (item 14). Overconfidence is the maximum value for Holder67 for a given CEO where Holder67 is a dummy equal to 1 for all CEO years after the CEO fails to exercise an option $67 \%$ in the money with 5 years remaining duration. BGV fixed effects are based on including pre-sample means of the dependent variable. All models control for $\ln (\mathrm{R} \& \mathrm{D}$ Stock), $\ln$ (Sales), $\ln \left(\right.$ Capital/Labor) and CEO Age, Age ${ }^{2}$, Tenure and Tenure ${ }^{2}$. 
Figure 1: Switching to Overconfident CEOs (Annual Treatment Effects)

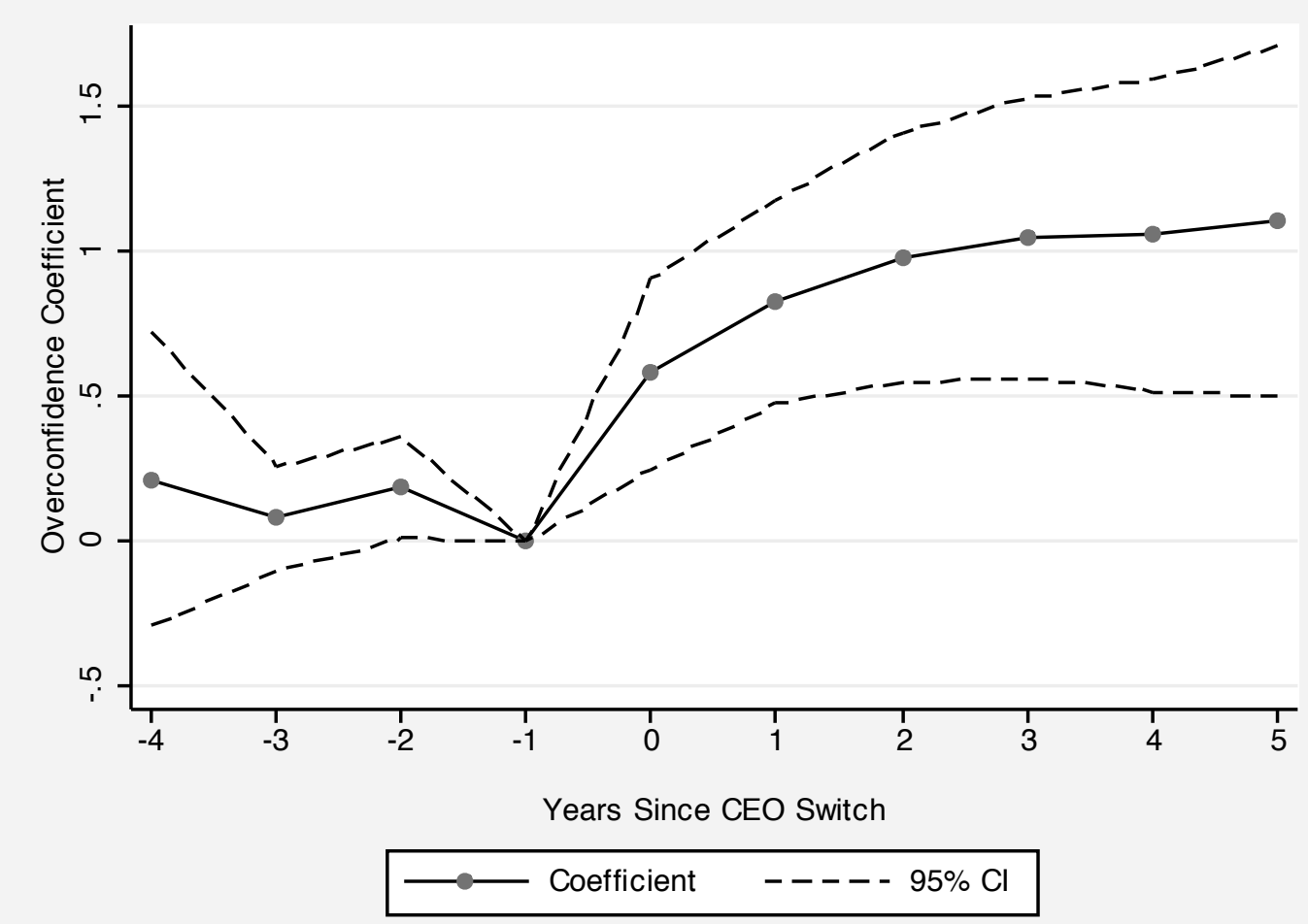

This figure plots coefficient estimates and robust standard errors from a Poisson regression with firm conditional fixed effects, a full set of calendar year effects, and a full set of year-relative-to-CEO-switch dummies (omitting the year prior to the change in CEO). The dependent variable is Total Cites. The estimation sample contains four years prior to the CEO switch and all years following the switch for all firms that replace a non-Overconfident CEO with an Overconfident CEO. 


\section{Appendix A: Extensions to the Theoretical Model}

\section{Non-Sector Specific Ability}

In the baseline model we assumed that CEO talent is sector specific and that after relocating to a new sector the CEO receives a compensation that does not depend on his past performance:

$$
\underline{w}=\frac{1}{2} \bar{\theta}-\delta
$$

We now relax this assumption and consider the case in which managerial ability is the same in all sectors. This implies that after low revenue realization the compensation obtained in a different sector will be

$$
\underline{w}=w_{2}\left(y_{1}=0\right)-\delta=\frac{1-p}{2-p-\alpha p} \bar{\theta}-\delta
$$

and that a CEO will never switch sector as long as $\delta>0$. If $i=1$, CEO's expected period 2 compensation is:

$$
\begin{aligned}
U(i & =1)=\left[\frac{1}{2}(1+o) p+\frac{1}{2}(1-o) \alpha p\right] \frac{\bar{\theta}}{1+\alpha} \\
& +\left[\frac{1}{2}(1+o)(1-p)+\frac{1}{2}(1-o)(1-\alpha p)\right]\left(\frac{1-p}{2-p-\alpha p} \bar{\theta}\right) \\
& =\frac{1}{2} p \bar{\theta}+\frac{1}{2}(2-p-\alpha p) \frac{1-p}{2-p-\alpha p} \bar{\theta} \\
& +o \frac{p}{2}(1-\alpha)\left(\bar{\theta} \frac{(1-\alpha)}{(\alpha+1)(2-p-\alpha p)}\right) .
\end{aligned}
$$

Because innovation occurs only if $I \leq \widehat{I}=U(i=1)-U(i=0)$ and $U(i=0)=\bar{\theta} / 2$ does not depend on overconfidence $\partial U(i=1) / \partial o \geq 0$ implies that $\partial \widehat{I} / \partial o>0$. Moreover,

$$
\frac{\partial^{2} \widehat{I}}{\partial o \partial \pi}=p \bar{\theta} \frac{(1-\alpha)}{(\alpha+1)^{2}(p+p \alpha-2)^{2}}(3+\alpha-2 p(1+\alpha)) \geq 0
$$

so both of our testable implications hold in this alternative setting.

Aghion, Van Reenen and Zingales (2009) consider the extreme case in which, after a low revenue realization, the CEO leaves the firm and is never hired by other sectors i.e. $\underline{w}=0$. In this case the ex ante compensation of a manager that innovates is:

$$
U(i=1)=\frac{1}{2} p \bar{\theta}+o \frac{p}{2}(1-\alpha) \frac{\bar{\theta}}{1+\alpha} .
$$

Notice that $U(i=1)-U(i=0) \leq 0$ if $o=0$ (non-overconfident CEOs never innovate when 
$\underline{w}=0$ ) and that this difference becomes positive for overconfident CEOs as long as $p$ is not too small. Moreover $\partial U(i=1) / \partial o \geq 0$ and $\partial^{2} U(i=1) / \partial o \partial \pi \geq 0$ therefore this alternative model is also consistent with our testable predictions.

\section{No Switching Cost}

In the baseline model we assumed that when a CEO reallocates to another sector he sustains a switching $\operatorname{cost} \delta$. If CEOs can switch costlessy $\underline{w}=\bar{\theta} / 2$. The absence of switching costs renders innovation more appealing because there is a higher payoff in the case of low revenue realization. Nevertheless, even in this alternative setting $\partial U(i=1) / \partial o \geq 0$ and $\partial^{2} U(i=1) / \partial o \partial \pi \geq 0$. Therefore the assumption that $\delta>0$ has no impact on our testable predictions.

\section{No Innovation Cost}

In the baseline model we assumed that the CEO sustains a private cost $I$ when he innovates. If we remove this cost innovation occurs as long as $U(i=1) \geq U(i=0)$ that is satisfied as long as the switching cost is not too large:

$$
\delta \leq \widehat{\delta}=p \theta(\alpha-1) \frac{o+\alpha-o \alpha+1}{2 p-4 \alpha+4 p \alpha+2 p \alpha^{2}+2 o p-2 o p \alpha^{2}-4} .
$$

Also in this framework innovation takes place for a larger range of parameters when the CEO is overconfident:

$$
\frac{\partial \widehat{\delta}}{\partial o}=p \theta \frac{(\alpha-1)^{2}}{(\alpha+1)(p+p \alpha+o p-o p \alpha-2)^{2}} .
$$

The cross partial derivative

$$
\frac{\partial^{2} \widehat{\delta}}{\partial o \partial \alpha}=p \theta \frac{(1-\alpha)\left(2 \alpha-5 p-4 p \alpha+p \alpha^{2}-o p+2 o p \alpha-o p \alpha^{2}+6\right)}{(\alpha+1)^{2}(p+p \alpha+o p-o p \alpha-2)^{3}}<0
$$

and therefore overconfidence and competition are complements (i.e. $\partial^{2} \widehat{\delta} / \partial o \partial \pi>0$ ) as in our baseline model. To see this notice that the second term in the denominator is negative because

$$
\begin{aligned}
p+p \alpha+o p-o p \alpha-2 & = \\
p(1+\alpha)+o p(1-\alpha)-2 & \leq \\
2 p-2 & \leq 0 .
\end{aligned}
$$

The term $2 \alpha-5 p-4 p \alpha+p \alpha^{2}-o p+2 o p \alpha-o p \alpha^{2}+6$ in the numerator is positive as long 


$$
p \leq \widetilde{p}(o)=\frac{2 \alpha+6}{o(1-\alpha)^{2}+4 \alpha-\alpha^{2}+5}
$$

and because $\widetilde{p}(o)<0$ and $\widetilde{p}(1)=1$ the term is positive for any value of $\alpha$ and $o$.

\section{Competition Affects Non-Innovating Managers}

We now relax the assumption that $U(i=0)$ is not affected by product market competition and extend the model assuming that competition affects non-innovating managers because it forces them to relocate to a different sector. We follow Aghion, Van Reenen and Zingales (2009) and assume that with probability $f(\pi)$ a non innovating firm incurs a loss and that $f^{\prime}(\pi)>0$. We also assume that that the CEO must relocate whenever the loss is incurred. In this case the CEO payoff without innovation is:

$$
U(i=0)=(1-f(\pi)) \frac{\bar{\theta}}{2}+f(\pi) \underline{w} .
$$

Because an increase in $\pi$ increases the net gain $U(i=1)-I-U(i=0)$, competition renders innovation more appealing. It is important to notice that in this setting, as in our baseline model, $U(i=0)$ does not depend on $o$. This implies that the two testable predictions of our baseline model hold in this alternative environment. ${ }^{13}$

\section{Generalization of the Competition Effect}

In the baseline model we assumed that the difference in talent between high and low quality CEOs was captured by $\alpha=1-\pi$. We now generalize the framework by assuming that if the CEO innovates $(i=1)$, the period 1 revenue realization is equal to:

$$
y_{1}=\left\{\begin{array}{cl}
1 \text { with probability } p(\pi) \\
0 & \text { with probability } 1-p(\pi)
\end{array}\right.
$$

if $\theta=\bar{\theta}$ and it is equal to

\footnotetext{
${ }^{13}$ If the probability of incurring the loss is also affected by overconfidence (i.e. $f(o, \pi)$ with $\left.\partial f / \partial o<0\right)$ an increase in $o$ increases innovation as long as:$$
\left|\frac{\partial f}{\partial o}\right|<\frac{\frac{p}{2}(1-\alpha)\left(\frac{\bar{\theta}}{1+\alpha}-\underline{w}\right)}{\left(\frac{\bar{\theta}}{2}-\underline{w}\right)} .
$$ 


$$
y_{1}=\left\{\begin{array}{c}
1 \text { with probability } q(\pi) \\
0 \text { with probability } 1-q(\pi)
\end{array}\right.
$$

if ability is low. We assume $q^{\prime}(\pi)<p^{\prime}(\pi)<0$ and $q(\pi) \leq p(\pi)$ : competition reduces the likelihood of high revenue but its effect is stronger for low ability CEOs. In this setting

$$
w_{2}\left(y_{1}=1\right)=\frac{p(\pi)}{p(\pi)+q(\pi)} \bar{\theta}
$$

and there is no change in

$$
\underline{w}=\frac{1}{2} \bar{\theta}-\delta
$$

Notice that

$$
\begin{aligned}
U(i & =1)=\left[\frac{1}{2}(1+o) p(\pi)+\frac{1}{2}(1-o) q(\pi)\right] w_{2}\left(y_{1}=1\right) \\
& +\left[\frac{1}{2}(1+o)(1-p(\pi))+\frac{1}{2}(1-o)(1-q(\pi))\right] \underline{w}
\end{aligned}
$$

and that the CEO innovates when $U(i=1)-I \geq U(i=0)$. Therefore innovation occurs in equilibrium only if innovation costs are not too large, specifically:

$$
I \leq \widehat{I}=U(i=1)-U(i=0)
$$

Because

$$
\frac{\partial \widehat{I}}{\partial o}=\frac{1}{2}(p(\pi)-q(\pi))\left(w_{2}\left(y_{1}=1\right)-\underline{w}\right)>0
$$

the first testable prediction holds in this generalized setting. Moreover:

$$
\frac{\partial^{2} \widehat{I}}{\partial o \partial \pi}=\frac{1}{2}\left(w_{2}\left(y_{1}=1\right)-\underline{w}+(p(\pi)-q(\pi)) \frac{p(\pi)}{(p(\pi)+q(\pi))^{2}}\right)\left[p^{\prime}(\pi)-q^{\prime}(\pi)\right]>0
$$

because $p^{\prime}(\pi)-q^{\prime}(\pi)>0$ so the second testable prediction is also valid.

\section{Competition reduces the impact of talent}

In the baseline model we assumed that $\alpha=1-\pi$. This assumption implies that product market competition affects the probability that low ability CEOs have of generating high revenue from an innovation and that talent is more valuable in a competitive environment rather than in a

non-competitive environment. We now follow Aghion, Van Reenen and Zingales (2009) and 
assume that $p=1-\pi$ and that $\alpha$ does not depend on $\pi$. Notice that in this variant of the model talent is more valuable when competition is less intense.

In this alternative setting the direct effect of overconfidence on innovation is analogous to the one in our baseline model:

$$
\frac{\partial \widehat{I}}{\partial o}=\frac{p}{2}(1-\alpha)\left(\frac{\bar{\theta}}{1+\alpha}-\underline{w}\right)>0 .
$$

Nevertheless, because talent is less valuable when competition is intense, the cross partial derivative has the opposite sign than the one in our model:

$$
\frac{\partial^{2} \widehat{I}}{\partial o \partial \pi}=-\frac{1}{2}(1-\alpha)\left(\frac{\bar{\theta}}{1+\alpha}-\underline{w}\right)<0 .
$$

Therefore the impact of overconfidence on innovation is lower when $\pi$ is large and the second testable prediction of our baseline model no longer holds.

It is important to notice that, despite the negative cross partial derivative, this alternative framework can still provide support to the idea that only overconfident CEOs innovate when competition is intense. To see this let us fix the level of innovation cost $I$. Notice that $U(i=$ 1) $-I>U(i=0)$ as long as

$$
p>\widehat{p}(o)=\frac{(2 I-2 \underline{w}+\bar{\theta})}{(1+\alpha+o(1-\alpha))} \frac{(1+\alpha)}{(\bar{\theta}-\underline{w}(1+\alpha))}
$$

and that $\widehat{p}$ is decreasing in $o$. This implies that non overconfident CEOs will innovate only if the level of product market competition is below $1-\widehat{p}(0) \equiv \pi^{0}$. Therefore when $\pi \leq \pi^{0}$ both overconfident and non-overconfident CEOs innovate whereas if $\pi>\pi^{0}$ only overconfident CEOs innovate. 


\section{Appendix B: Additional Empirical Results}

Table B1: Overconfidence and Innovation (Conditional FEs)

\begin{tabular}{|c|c|c|c|c|}
\hline \multicolumn{5}{|c|}{$\begin{array}{c}\text { Poisson Panel Regressions } \\
\text { Unit of Observation = Firm-Year } \\
\text { Dependent Variable = Total Citations } \\
\end{array}$} \\
\hline & (1) & $(2)$ & (3) & (4) \\
\hline Overconfidence & $\begin{array}{c}0.319^{* *} \\
(0.14)\end{array}$ & & $\begin{array}{c}0.780^{* * *} \\
(0.28)\end{array}$ & \\
\hline Holder67 & & $\begin{array}{c}0.256^{* *} \\
(0.12)\end{array}$ & & $\begin{array}{c}0.910^{* *} \\
(0.39)\end{array}$ \\
\hline Lerner Index & & & $\begin{array}{l}1.435 \\
(3.01)\end{array}$ & $\begin{array}{l}-1.141 \\
(2.49)\end{array}$ \\
\hline Lerner x Overconf & & & $\begin{array}{c}-4.053^{* *} \\
(1.85)\end{array}$ & \\
\hline Lerner x Holder67 & & & & $\begin{array}{c}-6.018^{* *} \\
(2.76)\end{array}$ \\
\hline Year Effects & Yes & Yes & Yes & Yes \\
\hline CEO Controls & Yes & Yes & Yes & Yes \\
\hline Firm Effects & Yes & Yes & Yes & Yes \\
\hline Observations & 1678 & 1041 & 1678 & 1041 \\
\hline Firms & 155 & 145 & 155 & 145 \\
\hline CEOs & 212 & 201 & 212 & 201 \\
\hline \multicolumn{5}{|c|}{$\begin{array}{l}\text { Cluster robust standard errors in parentheses: } * 10 \% \text { significance; } * * 5 \% \\
\text { significance; } * * * 1 \% \text { significance. Overconfidence is the maximum value } \\
\text { for Holder } 67 \text { for a given CEO where Holder } 67 \text { is a dummy equal to } 1 \\
\text { for all CEO years after the CEO fails to exercise an option } 67 \% \text { in the } \\
\text { money with } 5 \text { years remaining duration. Lerner Index is the median } \\
\text { gross profit margin of all Compustat firms in a } 2 \text {-digit SIC code (see } \\
\text { text). CEO controls are Age, } \text { Age }^{2} \text {, Tenure and Tenure }\end{array}$} \\
\hline
\end{tabular}


Table B2: Overconfidence and Innovation (CEO Switches)

\begin{tabular}{|c|c|c|c|c|c|c|}
\hline \multicolumn{7}{|c|}{$\begin{array}{c}\text { Poisson Panel Regressions } \\
\text { Unit of Observation = Firm-Year }\end{array}$} \\
\hline \multirow[t]{2}{*}{ Outcome Variable } & \multicolumn{2}{|c|}{$\begin{array}{l}\text { Cite-Weighted } \\
\text { Patents } \\
\end{array}$} & \multicolumn{2}{|c|}{$\begin{array}{c}\text { Unweighted } \\
\text { Patents } \\
\end{array}$} & \multicolumn{2}{|c|}{$\begin{array}{l}\text { Cites per } \\
\text { Patent }\end{array}$} \\
\hline & (1) & $(2)$ & $(3)$ & $(4)$ & $(5)$ & (6) \\
\hline Overconfidence & $\begin{array}{c}0.443^{* *} \\
(0.20)\end{array}$ & $\begin{array}{l}0.516^{* * *} \\
(0.15)\end{array}$ & $\begin{array}{l}0.249 \\
(0.17)\end{array}$ & $\begin{array}{c}0.257^{*} \\
(0.15)\end{array}$ & $\begin{array}{l}0.354^{* * *} \\
(0.13)\end{array}$ & $\begin{array}{r}0.247^{*} \\
(0.13)\end{array}$ \\
\hline Pre-Overconf x T & $\begin{array}{l}0.100 \\
(0.09)\end{array}$ & & $\begin{array}{l}0.081 \\
(0.09)\end{array}$ & & $\begin{array}{r}-0.072 \\
(0.06)\end{array}$ & \\
\hline Pre-Switch x T & $\begin{array}{l}0.024 \\
(0.04)\end{array}$ & & $\begin{array}{l}0.013 \\
(0.03)\end{array}$ & & $\begin{array}{l}0.029 \\
(0.03)\end{array}$ & \\
\hline Year Effects & Yes & Yes & Yes & Yes & Yes & Yes \\
\hline CEO Controls & Yes & No & Yes & No & Yes & No \\
\hline Firm Effects & Yes & Yes & Yes & Yes & Yes & Yes \\
\hline Observations & 560 & 280 & 560 & 280 & 560 & 280 \\
\hline Firms & 52 & 28 & 52 & 28 & 52 & 28 \\
\hline CEOs & 79 & 41 & 79 & 41 & 79 & 41 \\
\hline
\end{tabular}


Table B3: Overconfident CEOs in Table B2

\begin{tabular}{|c|c|c|c|}
\hline & Company Name & CEO Name & Year Hired \\
\hline 1 & ALCOA & O'Neill Paul H. & 1987 \\
\hline 2 & AMAX INC & Born Allen & 1986 \\
\hline 3 & AMERICAN BRANDS INC & Alley William J. & 1987 \\
\hline 4 & $\mathrm{AT} \& \mathrm{~T} \mathrm{CO}$ & Allen Robert E. & 1988 \\
\hline 5 & C B I INDUSTRIES INC & Jones John E. & 1989 \\
\hline 6 & CABOT CORP & Bodman Samuel W. & 1988 \\
\hline 7 & CATERPILLAR INC & Fites Donald V. & 1990 \\
\hline 8 & COLGATE PALMOLIVE CO & Mark Reuben & 1984 \\
\hline 9 & COORS ADOLPH CO & Coors Jeffrey H. & 1985 \\
\hline 10 & DEERE \& CO & Bechere Hans W. & 1990 \\
\hline 11 & E G \& G INC & Kucharski John M. & 1987 \\
\hline 12 & ENGELHARD CORP & Smith Orin R. & 1984 \\
\hline 13 & GOODYEAR TIRE \& RUBR CO & Mercer Robert E. & 1983 \\
\hline 14 & GULF \& WESTERN INDS INC & Davis Martin S. & 1983 \\
\hline 15 & HERSHEY FOODS CORP & Zimmerman Richard A. & 1984 \\
\hline 16 & INTEL CORP & Grove Andrew S. & 1987 \\
\hline 17 & INTERNATIONAL PAPER CO & Georges John A. & 1985 \\
\hline 18 & MEAD CORP & Roberts Burnell R. & 1981 \\
\hline 19 & MOTOROLA INC & Fisher George M. C. & 1988 \\
\hline 20 & NICOR INC & Cline Richard G. & 1986 \\
\hline 21 & P P G INDUSTRIES INC & Sarni Vincent A. & 1985 \\
\hline 22 & PACIFIC TELESIS GROUP & Ginn Sam L. & 1988 \\
\hline 23 & RORER GROUP INC & Cawthorn Robert E. & 1985 \\
\hline 24 & RYDER SYSTEMS INC & Burns M. Anthony & 1983 \\
\hline 25 & SEARS ROEBUCK \& CO & Brennan Edward A. & 1986 \\
\hline 26 & TAMPAX INC & Shutt Edwin H. & 1982 \\
\hline 27 & TOSCO CORP & O'Malley Thomas D. & 1990 \\
\hline 28 & U S WEST INC & McCormick Richard D. & 1991 \\
\hline
\end{tabular}


Table B4: Overconfidence and Innovation (Robustness Checks)

\begin{tabular}{|c|c|c|c|c|}
\hline \multicolumn{5}{|c|}{$\begin{array}{l}\text { Panel Regressions } \\
\text { Unit of Observation = Firm-Year } \\
\text { Dependent Variable = Total Cites }\end{array}$} \\
\hline \multirow[t]{2}{*}{ Specification } & Poisson & Poisson & Poisson & NegBin \\
\hline & $(1)$ & $(2)$ & $(3)$ & $(4)$ \\
\hline Overconfidence & $\begin{array}{c}0.241^{* *} \\
(0.12)\end{array}$ & $\begin{array}{c}0.246^{* *} \\
(0.12)\end{array}$ & $\begin{array}{l}0.063^{*} \\
(0.03)\end{array}$ & $\begin{array}{c}0.527^{* * *} \\
(0.17)\end{array}$ \\
\hline Vested Options & $\begin{array}{c}0.004^{* * *} \\
(0.00)\end{array}$ & & & \\
\hline Stock Ownership & $\begin{array}{c}-0.626 \\
(2.30)\end{array}$ & & & \\
\hline Finance Education & & $\begin{array}{r}-0.081 \\
(0.19)\end{array}$ & & \\
\hline Technical Education & & $\begin{array}{c}0.139 * * \\
(0.06)\end{array}$ & & \\
\hline $\ln \left(\right.$ Cites $\left._{t-1}\right)$ & & & $\begin{array}{c}0.812^{* * *} \\
(0.03)\end{array}$ & \\
\hline Year Effects & Yes & Yes & Yes & Yes \\
\hline SIC 2-digit Effects & Yes & Yes & Yes & Yes \\
\hline Firm Effects & BGV & BGV & BGV & BGV \\
\hline Observations & 2200 & 1491 & 2037 & 2411 \\
\hline Firms & 207 & 153 & 206 & 227 \\
\hline CEOs & 277 & 177 & 275 & 301 \\
\hline
\end{tabular}

Cluster robust standard errors in parentheses: $* 10 \%$ significance; $* * 5 \%$ significance; ***1\% significance. Overconfidence is the maximum value for Holder67 for a given CEO where Holder67 is a dummy equal to 1 for all CEO years after the CEO fails to exercise an option $67 \%$ in the money with 5 years remaining duration. BGV fixed effects are based on including pre-sample means of the dependent variable. All models control for $\ln \left(\right.$ R\&D Stock), $\ln$ (Sales), $\ln$ (Capital/Labor) and CEO Age, Age ${ }^{2}$, Tenure and Tenure ${ }^{2}$. 
Table B5: Overconfidence and Innovation (ExecuComp Sample)

\begin{tabular}{|c|c|c|c|c|}
\hline \multicolumn{5}{|c|}{$\begin{array}{c}\text { Poisson Panel Regressions } \\
\text { Unit of Observation = Firm-Year } \\
\text { Dependent Variable = Total Citations }\end{array}$} \\
\hline & (1) & $(2)$ & $(3)$ & $(4)$ \\
\hline Holder67-EC & $\begin{array}{c}0.257^{* * * *} \\
\quad(0.10)\end{array}$ & & $\begin{array}{c}0.409^{* * *} \\
(0.09)\end{array}$ & \\
\hline Overconfident-EC & & $\begin{array}{c}0.379^{* *} \\
(0.17)\end{array}$ & & $\begin{array}{c}0.507^{* * *} \\
(0.13)\end{array}$ \\
\hline Lerner50 x Holder67-EC & & & $\begin{array}{c}-1.223^{* * *} \\
(0.09)\end{array}$ & \\
\hline Lerner50 x Overconf-EC & & & & $\begin{array}{c}-0.665^{* *} \\
(0.32)\end{array}$ \\
\hline Year Effects & Yes & Yes & Yes & Yes \\
\hline SIC 2-digit Effects & Yes & Yes & Yes & Yes \\
\hline Firm Effects & $\mathrm{BGV}$ & BGV & BGV & BGV \\
\hline Observations & 4799 & 7123 & 4799 & 7123 \\
\hline Firms & 1245 & 1491 & 1245 & 1491 \\
\hline CEOs & 1360 & 1674 & 1360 & 1674 \\
\hline
\end{tabular}

